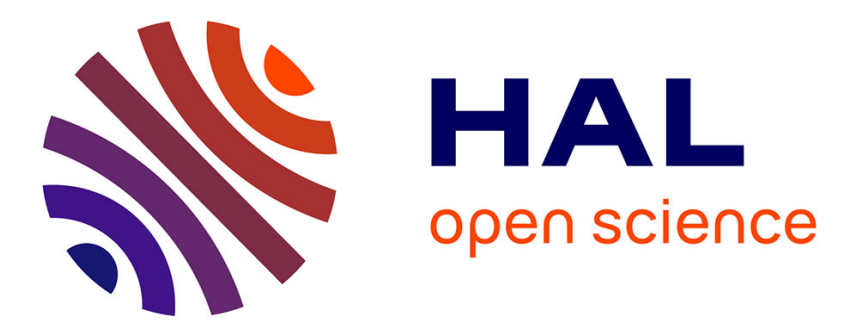

\title{
New sedimentological and palynological data from the Permian and Triassic series of the Sancerre-Couy core, Paris Basin, France
}

\author{
Manuel A Juncal, Sylvie Bourquin, Laurent Beccaletto, José B Diez
}

\section{To cite this version:}

Manuel A Juncal, Sylvie Bourquin, Laurent Beccaletto, José B Diez. New sedimentological and palynological data from the Permian and Triassic series of the Sancerre-Couy core, Paris Basin, France. Geobios, 2018, 51 (6), pp.517-535. 10.1016/j.geobios.2018.06.007 . insu-01840103

HAL Id: insu-01840103

https://hal-insu.archives-ouvertes.fr/insu-01840103

Submitted on 16 Jul 2018

HAL is a multi-disciplinary open access archive for the deposit and dissemination of scientific research documents, whether they are published or not. The documents may come from teaching and research institutions in France or abroad, or from public or private research centers.
L'archive ouverte pluridisciplinaire HAL, est destinée au dépôt et à la diffusion de documents scientifiques de niveau recherche, publiés ou non, émanant des établissements d'enseignement et de recherche français ou étrangers, des laboratoires publics ou privés. 


\section{Accepted Manuscript}

Title: New sedimentological and palynological data from the Permian and Triassic series of the Sancerre-Couy core, Paris Basin, France

Author: Manuel A. Juncal Sylvie Bourquin Laurent Beccaletto José B. Diez

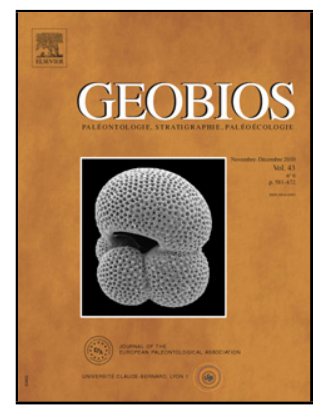

PII:

DOI:

Reference: S0016-6995(17)30179-1

To appear in: Geobios

Received date: $\quad 13-12-2017$

Accepted date: $\quad$ 19-6-2018

Please cite this article as: Juncal, M.A., Bourquin, S., Beccaletto, L., Diez, J.B.,New sedimentological and palynological data from the Permian and Triassic series of the Sancerre-Couy core, Paris Basin, France, Geobios (2018), https://doi.org/10.1016/j.geobios.2018.06.007

This is a PDF file of an unedited manuscript that has been accepted for publication. As a service to our customers we are providing this early version of the manuscript. The manuscript will undergo copyediting, typesetting, and review of the resulting proof before it is published in its final form. Please note that during the production process errors may be discovered which could affect the content, and all legal disclaimers that apply to the journal pertain. 
New sedimentological and palynological data from the Permian and Triassic series of the Sancerre-Couy core, Paris Basin, France

Manuel A. Juncal ${ }^{a}$, , Sylvie Bourquin ${ }^{\mathrm{b}}$, Laurent Beccaletto ${ }^{\mathrm{c}}$, José B. Diez ${ }^{\mathrm{a}}$

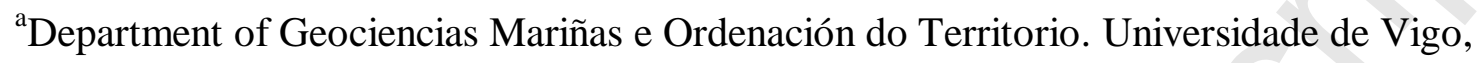

Campus universitario Lagoas-Marcosende, 36310 Vigo, Spain

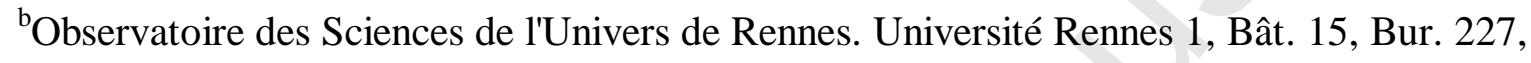
Campus de Beaulieu, CS 74205, 35042 Rennes cedex, France

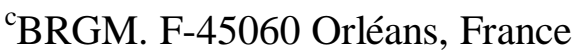

* Corresponding author. E-mail address: majuncales@uvigo.es (M.A. Juncal).

* Corresponding editor: Borja Cascales-Miñana.

Abstract

A new description and sampling campaign of the Sancerre-Couy core has been achieved to reconstruct the evolution of the depositional environments of the Permian and Triassic series and the palynological evolution of the Permian to Lower Jurassic series. High-resolution sequence stratigraphy of the Permian and Triassic series of the Paris Basin, based on well-log 
analysis, is used to determine seven progradational-retrogradational cycles in the Permian and twelve cycles in the Triassic. Out of the 54 samples collected from the Sancerre-Couy- 1 core, only 23 were palynologically productive. Based on the taxonomic composition, four palynological assemblages are distinguished, three of which have been described in previous studies. These three classical palynological assemblages of the Sancerre-Couy-1 core are documented in detail for the first time in this present study. The description of the new assemblage and its correlation can be used to reassess the previously assigned ages: assemblage SC-1 is late Ladinian in age, SC-2 is of the Ladinian-Carnian transition, SC-3 is early Carnian in age, and SC-4 is of late Rhaetian age whereas it had previously been assigned a Hettangian age.

\section{Keywords}

Palynostratigraphy; Depositional environment; Middle-Upper Triassic; Ladinian; Carnian; Rhaetian

\section{Introduction}

Late Carboniferous (Stephanian) to Permian basins cropping out in and around the presentday French Variscan basement were initiated during the latest extensional stages of the Variscan orogeny (Echtler and Malavieille, 1990; Burg et al., 1994; Praeg, 2004; Fig. 1(A)). These basins are also identified in the subsurface beneath the Meso-Cenozoic sedimentary cover of the Paris Basin, but without any clear tectono-sedimentary framework (Mascle, 1990; Perrodon and Zabek, 1990; Delmas et al., 2002). More recently, the geometry and 
structural evolution of the Stephano-Permian basins located in the south-western part of the Paris Basin have been studied using seismic data (Beccaletto et al., 2015). However, the lack of core data means that it was neither possible to provide a precise description of the depositional environment and age assessment nor their sedimentary succession. The Triassic deposits then overly the Permian deposits through an angular unconformity, as seen in the western part of the Germanic Basin (i.e., more or less at the place of the present-day Paris Basin; Bourquin et al., 2006).

The Sancerre-Couy-1 core was drilled in 1986 in the south-western part of the Paris Basin, 30 km west of the city of Bourges (Chantraine et al., 1992; Figs. 1(B), 2). The primary target of this scientific well was the study of the PBMA (Paris Basin Magnetic Anomaly), a major magnetic anomaly situated in the basement of the Paris Basin; unfortunately, the deep source rock of the PBMA was not reached. The Sancerre-Couy-1 core cut through a preserved Permian to Jurassic sedimentary succession. So far, only scarce data have been published from this well regarding the Permian (Orszag-Sperber et al., 1992) or Triassic sedimentary evolution (Adloff et al., 1992). This paper presents the results of a new description and sampling campaign carried out to restudy the Sancerre-Couy-1 core. We specify precise changes in the depositional environment of the Permian to Early Jurassic succession and characterise the palynological content.

\section{Geological setting}

\subsection{Paris Basin}

The Paris Basin, located in northern France, is a low subsidence Meso-Cenozoic intracratonic sedimentary basin set up on a Variscan substratum that includes late Carboniferous-Permian basins (Fig. 1). The latter were identified using subsurface geophysics and well data; 
generally speaking, there is no consensus with regard to their extension and geological evolution (Mégnien, 1980; Mascle, 1990; Perrodon and Zabeck, 1990; Autran et al., 1994; Guillocheau et al., 2000). A recent study describes the palaeogeographic extent of the Stephano-Permian basins beneath the Mesozoic series in the south-western Paris Basin and delineates how the sediments were deposited during two successive tectonic phases (Beccaletto et al., 2015). However, the lack of high-resolution core data in the Paris Basin makes it difficult to provide a precise description of the depositional environment and to date the Palaeozoic sedimentary deposits.

South-east of the Sancerre-Couy core, several isolated (late Carboniferous-Permian subbasins also outcrop over the deformed magmatic and metamorphic rocks of the French Massif Central (Aumance, Autun, Decize-La Machine, Blanzy-Le Creusot, Fig. 1(B); Marteau, 1983; Vallé, 1986; Paquette and Feys, 1989; Roger et al., 2010). Recently, new accurate CA-IDTIMS U-Pb zircon ages recorded from tonsteins have been used to date the Gzelian-Permian transition in the Autun sub-basin (Pellenard et al., 2017).

Within the Paris Basin, the Triassic succession progressively onlaps on the pre-Triassic unconformity (Bourquin et al., 2006). During the Early and Middle Triassic, the Paris Basin corresponds to the western part of the Germanic Basin (Bourquin et al., 2011) and become an independent basin from the middle Carnian (Late Triassic) onward (Bourquin and Guillocheau, 1993, 1996). The Triassic evolution of the Paris Basin is well known based on sequence stratigraphy correlations using well-log, core and outcrop data. These have been used to reconstruct isopach and palaeoenvironmental maps (Bourquin et al., 1995, 2002, 2011). However, biostratigraphic ages of the sedimentary succession are very scarce and documented primarily from outcrop data in the eastern part of the basin. 


\subsection{The Sancerre-Couy-1 well}

The Sancerre-Couy-1 well was cored and well-logged in the southwestern part of the Paris Basin (Fig. 1(B)). The fully cored well starts in the Callovian sediments outcropping in this part of the basin. The base of the core reached the amphibolite basement at a depth of $3500 \mathrm{~m}$. The basement, composed of metamorphic rocks and starting at a depth of $941.65 \mathrm{~m}$, is overlain by the Palaeozoic sedimentary series (Lorenz et al., 1987). The latter is composed of volcanoclastic deposits until a depth of $925.35 \mathrm{~m}$, attributed to the Stephanian (Chantraine et al., 1992). Trachyandesites sampled at the bottom of the Stephanian unit yield an Ar-Ar age of $301 \mathrm{Ma}$ (Costa and Maluski, 1988). The core is deposited at the BRGM in Orleans, France. The Stephanian volcaniclastic unit is overlain by Permian fluvio-lacustrine deposits with an angular discordance (Lorenz et al., 1987). These sediments are attributed to the late Permian based on the presence of several Darwinulacea ostracods (Orszag-Sperber et al., 1992).

The Permian sediments are overlain by the Triassic succession (from $809.8 \mathrm{~m}$ to $559.6 \mathrm{~m}$ deep). Courel et al. (1990) distinguishes the following Triassic formations: fluvial deposits at the base ('Grès argileux de base' Fm.), a shallow lagoon-marine deposits with tidal influences ('Grès infra-anhydritique' Fm.) and evaporitic deposits ('Argile à anhydrite' Fm., 'Grès supra-anhydritique’ Fm., and ‘Argile de Chalain’ Fm.) (Fig. 2). Sporomorph assemblages indicate a late Ladinian to Carnian age for the basal part of the Argile à anhydrite Fm. (Adloff et al., 1987, 1992). In comparison with the Massif Central area, Courel et al. (1990) consider the Grès infra-anhydritique Fm. as the maximum coastal onlap onto the late Variscan palaeoreliefs.

The first levels, considered as Jurassic (559.6 m; Fig. 2), are composed of coarse sandstones, with coal fragments and bivalves, progressively overlain by carbonate deposits around $542 \mathrm{~m}$ (Lorenz, 1992; Fig. 2). These sandstone and carbonate deposits were attributed to the 
Hettangian, without any biostratigraphic constraint. Gély and Lorenz (1991) identified the Hettangian-Sinemurian boundary (at $508.20 \mathrm{~m}$ ) based on the lithostratigraphy and by correlating the logging tools throughout the Paris Basin. Only the occurrence of bioclastic limestone with Gryphaea, starting at a depth of $508.2 \mathrm{~m}$, suggests the Sinemurian stage (Lorenz, 1992).

\section{Material and methods}

The Sancerre-Couy- 1 core was used to establish a detailed sedimentological log from the basement (925.35 m) up to the supposed Hettangian interval (553 m; Chanteraine et al., 1992; Lorenz, 1992) at a 1:50 scale. Fifty-four samples (PC-01 to PC-54) were collected from the Sancerre-Couy-1 core; the levels with the most organic matter and finest grain size for palynological studies were selected. Twenty-three of the 54 collected samples are productive. Samples were processed in the laboratory of the Geosciences Department at the University of Vigo in Spain, using standard palynological HCl-HF-HCl techniques. The samples were processed by first adding $\mathrm{HCl}$ and $\mathrm{HF}$ to remove the carbonate and silicate minerals. A dispersing agent was subsequently added to facilitate filtering. The residue was mounted on a glass slide and observed under a Nikon Bio-Rad confocal microscope at the CACTI Labs at the University of Vigo.

4. Depositional environment of the Permian and Triassic series and palynological analysis

\subsection{The Permian alluvial fan to shallow lake series}

In the Sancerre-Couy-1 core, the Permian sediments are mainly composed of siltstones with sandstones and few conglomerates (Table 1). The base of the series, from 925 to $894 \mathrm{~m}$, is 
mainly composed of conglomerates and sandstones with interbedded fine-grained facies. The conglomerates, which mainly display an erosive base, are constituted of very poorly sorted gravel to cobble-size quartz, feldspar, and silty, sandy and volcanic clasts. They are composed of massive matrix- (silt to sand) or clast-supported facies (Gmm and Gmc facies, respectively; Table 1) typical of debris or a hyper-concentrated flow process (Postma, 1990; Miall, 1996). In several cases, the conglomerates are clast-supported with either horizontal bedding (Gh facies; Table 1) or planar cross-stratification (Gp facies; Table 1), typical of a streamflow process (Postma, 1990; Miall, 1996). The sandstones are composed of massive fine to medium grains ( $\mathrm{Sm}$ facies) that are sometimes bioturbated (Smb facies; Table 1), which is typical for subaerial hyper-concentrated density flows or subaqueous high-density turbidity currents (Lowe, 1982; Mulder and Alexander, 2001). Features of a tractive current such as current ripples ( $\mathrm{Sr}$ facies; Table 1) or trough cross-stratification (St facies; Table 1) are observed. These indicate streamflow processes (Postma, 1990; Miall, 1996). This facies association corresponds to an alluvial-fan environment (Blair and McPherson, 1994) that is dominated by debris flows (sediment gravity flows and catastrophic fluid gravity flows). It is possible to distinguish a proximal alluvial fan facies association composed of a gravity flow process (Gmm, Gmc, and Sm facies) and a distal alluvial fan facies association with the development of streamflow processes ( $\mathrm{Gp}, \mathrm{Gh}, \mathrm{Sr}, \mathrm{Sm}$, and St facies). The predominantly fine-grained sediments consist of massive or laminated silts ( $\mathrm{F}$ facies) or are composed of a heterolithic facies (Fl facies; Table 1), which are sometimes bioturbated (Fb and Flb facies, monospecific for the Scoyenia type). Sometimes massive or finely laminated dolomite (Dm facies; Table 1) or oolitic facies (Fo facies; Table 1) are associated with fine-grained facies, indicating a constant water level, sometimes with high energy. Some $\mathrm{cm}$-scale levels with dolomite nodules may indicate the development of palaeosols (Dn facies; Table 1). The finegrained facies association is typical of floodplains ( $\mathrm{F}$ and $\mathrm{Fl}$ facies) or shallow lakes ( $\mathrm{Fb}$, Flb, 
Fo, and Dm facies). Consequently, the lower part of the Permian succession of the SancerreCouy-1 core shows three retrogradational-progradational sequences (noted PI, PII and PIII;

Fig. 3). These sequences are characterised by an increasing lacustrine influence with decreasing alluvial fan deposits towards the top (from PI to PIII). The retrogradational trend is marked by alluvial fan deposits, which evolve vertically to distal alluvial fans or floodplain and shallow lake environments. The progradational trend is marked by a change from lake to floodplain environments sometimes with palaeosol development.

From 894 to $811 \mathrm{~m}$, the Permian succession is characterised by the dominance of the above described fine-grained facies. Thin sandstone beds ( $\mathrm{cm}$ to $\mathrm{dm}$ in thickness) are intercalated into the fine-grained facies. They occur as massive beds (Sm facies; Table 1) with horizontal lamination (Sh facies; Table 1), current (Sr facies; Table 1) or wave ripples ( $\mathrm{Sw}$ facies; Table 1), and even with trough cross-stratification in rare cases (St facies; Table 1). They are frequently bioturbated (Smb and Srb facies; Table 1). This facies association is typical of subaqueous environments with frequent episodes of fluvial input, i.e., a shallow lake environment in semi-arid climate conditions as evidenced by carbonate facies ( $\mathrm{Dm}$ and Fn facies; Table 1; Hasiotis, 2006; Hasiotis et al., 2007). Consequently, four retrogradationalprogradational sequences (denoted as PIV to PVII; Fig. 3) are observed, with well-developed progradational trends towards proximal lacustrine depositional environments except for sequence PV, where the progradational trend ends with a floodplain, a distal alluvial fan environment, and probably a palaeosol (Fn facies; Table 1).

The Permian series shows a general trend from alluvial fan to shallow lake deposits. Unfortunately, all relevant palynological samples are barren (PC-01 to PC-05; Fig. 3).

\subsection{The fluvio-lacustrine and sebkha Triassic series}




\subsubsection{Depositional environment and retrogradational-progradational cycles}

The Triassic series studied here is composed of siliciclastic and anhydritic materials with very few dolomitic deposits (Fig. 4). The lower part, from 811 to $792 \mathrm{~m}$, is composed of conglomerates and sandstones with few silty levels (Fl facies; Table 1) that are primarily bioturbated (monospecific for the Scoyenia type Flb facies; Table 1). The conglomerates are composed of poorly-sorted gravel to pebbles, either massive matrix-supported (coarse sand) or clast-supported (Gmm and Gmc facies, respectively; Table 1), sometimes with crossbedding stratification (Gtp facies; Table 1). The sandstones are fine- to coarse-grained, either massive (Sm facies; Table 1) or displaying horizontal (Sh facies; Table 1) or cross-bedding stratification (St and Stp facies; Table 1), and are sometimes intensely bioturbated (monospecific for the Scoyenia type Sb, Shb, and Stb facies; Table 1). Locally, dolomite nodules may indicate the development of palaeosols (Dn facies). These deposits are mainly organised in normally graded sequences from conglomerates to fine bioturbated siltstones $(\mathrm{cm}$ to $\mathrm{dm}$ in thickness), typical of braided alluvial fan deposits within a shallow lake environment (Bourquin et al., 1998). The sediments of this depositional environment develop up-section into either silt and clay dominated facies (F facies; Table 1), and sometimes bioturbated (Fb facies; Table 1) or heterolithic facies (Fl and Flb facies; Table 1). The latter are composed of silt and clay with few very fine- to fine-grained sandstone beds ( $\mathrm{mm}$ to $\mathrm{cm}$ in thickness), with currents and more rarely oscillatory ripples ( $\mathrm{Fl}$ facies) that are frequently bioturbated (Flb facies). Clays may contain some anhydrite nodules (Fa facies; Table1). The depositional environment is attributed to a shallow lake environment with few fluvial inputs, which increases progressively from 780 to $733 \mathrm{~m}$. This first sequence (denoted as TI; Fig. 4) records a retrogradational trend with an evolution from a braided alluvial fan within a shallow lake environment, where the maximum retrogradation is located close to $780 \mathrm{~m}$. The progradational trend is marked by an increase in sediment supply that ends with a distal 
alluvial fan deposit within a playa lake, as evidenced by the presence of a higher frequency of anhydrite intervals (A and Fa facies; Table 1).

From 732 to $720 \mathrm{~m}$, the second sequence (denoted as TII; Fig. 4) only displays a retrogradational trend from a braided alluvial fan $(\mathrm{Gmc}, \mathrm{Gt}, \mathrm{Gh}, \mathrm{St}, \mathrm{Sb}$, and Flb facies association) to silty clay deposits ( $\mathrm{F}$ facies) that are sometimes bioturbated ( $\mathrm{Fb}$ facies) and include anhydrite nodule levels (A and Fa facies). These fine-grained facies, with $\mathrm{cm}$-scale beds of anhydritic nodules and few siliciclastic inputs, are typical of anhydrite sebkha (Bourquin and Guillocheau, 1993, 1996).

From 720 to $692 \mathrm{~m}$, the overlying siliciclastic deposits are finer and thinner, reflecting more distal fan-delta deposits (sand sheet, Fl, Sr, St, Fl, and Flb facies association). They are associated with anhydrite sebkha deposits (A facies association) with increased black silty clays contents (F facies), rich in palynomorphs (until $705 \mathrm{~m}$ ). This facies association reflects two sequences (denoted TIII and TIV; Fig. 4) that record a retrogradational and progradational trend where the maximum flooding episode is marked by black silty clays.

The fifth sequence (denoted as TV; Fig. 4) starts with few sand sheet deposits within a playa lake (Flb facies, with current and oscillatory ripples, associated with anhydritic nodules, A facies). The maximum flooding event is also marked by black clay. The progradational trend characterises an increase in the anhydritic level content associated with red clay, and ends with a well-developed, 1 m-thick anhydritic bed.

The sixth sequence (denoted as TVI; Fig. 4) displays red clay and anhydritic nodules that are increasingly less developed toward the top, attesting to a retrogradational trend. The progradational trend shows a fluvial sand sheet within playa-lake environment (Flb and Shb facies).

The seventh to eleventh sequences (denoted as TVII to TXII; Fig. 4) mainly record the 
retrogradational trend from a distal braided alluvial fan $(\mathrm{Gmm}, \mathrm{Gh}, \mathrm{St}, \mathrm{Stb}, \mathrm{Sh}$, and Shb facies association) and/or a fluvial sand sheet (Sh, Shb, Flb, and St facies association) within a shallow lake to lake environment (Flb and F facies association). The maximum flooding episodes are marked by massive bioturbated silty clays. However, the eleventh sequence records a well-developed progradational trend within a floodplain environment where dolomitic nodules attributed to dolocretes indicate the development of palaeosols (Fn and Dn facies).

\subsubsection{Palynological analysis of the Triassic series}

The first four samples (PC-06 to PC-09; Figs. 4, 5) collected in the Triassic levels did not yield any palynomorphs. The 23 productive samples are grouped into four palynological assemblages based on their taxonomical composition, three of which were described in previous studies: SC-1 is studied as the "second assemblage" in Adloff et al. (1987) and Courel et al. (1990), SC-2 as the "first assemblage" in Adloff et al. (1987), and SC-4 is studied in Lorenz et al. (1987). In addition, a new association (SC-3) is described from samples PC-39, PC-40 and PC-41. The studies mentioned above show preliminary species lists without any pictures. The present study allowed us not only to confirm the majority of the previous identifications, but also to identify a new palynological assemblage stratigraphically well constrained to the $698.45-697.45 \mathrm{~m}$ interval, and to reinterpret the 559.25-553 m levels previously attributed to the Hettangian (Early Jurassic; Fig. 5).

We identified the following taxa in the first palynological assemblage (SC-1: samples PC-10 to PC-17; Figs. 6, 7): Alisporites grauvogeli Klaus, 1964, Alisporites opii Daugherty, 1941, Brachysaccus neomundanus (Leschik) Mädler, 1964, Calamospora tener (Leschik) Mädler, 1964, Camerosporites secatus Leschik, 1956, Chordasporites singulichorda Klaus, 1960, 
Duplicisporites granulatus (Leschik) Scheuring, 1970, Illinites chitonoides Klaus, 1964, Microcachryidites doubingeri Klaus, 1964, Ovalipollis pseudoalatus (Thiergart) Schuurman, 1976, Paracirculina scurrilis Scheuring, 1970, Porcellispora longdonensis (Clarke) Scheuring, 1970 emend. Morbey, 1975, Praecirculina granifer (Leschik) Klaus, 1960, Quadraeculina anellaeformis Maljavkina, 1949, Samaropollenites speciosus Goubin, 1965, Staurosaccites quadrifidus Dolby, 1976, Triadispora epigona Klaus, 1964, Triadispora falcata Klaus, 1964, Triadispora plicata Klaus, 1964, Triadispora staplinii (Jansonius) Klaus, 1964, Triadispora suspecta Scheuring, 1970, Triadispora verrucata (Schulz) Scheuring, 1970, Alisporites sp., Calamospora sp., Chordasporites sp., Cycadopites sp., and Duplicisporites sp.

The second palynological assemblage (SC-2: samples PC-27 to PC-38; Fig. 8) consists of: Alisporites grauvogeli Klaus, 1964, Aratrisporites granulatus Klaus, 1960, Camerosporites secatus Leschik, 1956, Duplicisporites granulatus (Leschik) Scheuring, 1970, Microcachryidites doubingeri Klaus, 1964, Ovalipollis pseudoalatus (Thiergart) Schuurman, 1976, Paracirculina scurrilis Scheuring, 1970, Paracirculina quadruplices Scheuring, 1970, Patinasporites densus Leschik, 1955, Porcellispora longdonensis (Clarke) Scheuring, 1970 emend. Morbey, 1975, Praecirculina granifer (Leschik) Klaus, 1960, Quadraeculina anellaeformis Maljavkina, 1949, Samaropollenites speciosus Goubin, 1965, Vallasporites ignacii Leschik, 1956, Alisporites sp., and Duplicisporites sp.

The new palynological assemblage (SC-3: samples PC-39 to PC-41; Figs. 9, 10) yields an assemblage characterised by: Alisporites grauvogeli Klaus, 1964, Alisporites opii Daugherty, 1941, Anapiculalisporites spiniger (Leschik) Reinhardt, 1962, Aulisporites astigmosus (Leschik) Klaus, 1960, Brodispora striata Clarke, 1965, Calamospora tener (Leschik) Mädler, 1964, Camerosporites secatus Leschik, 1956, Cibotiumspora juriensis (Balme) Filatoff, 1975, Cingulizonates cf. rhaeticus (Rheinhardt) Schulz, 1967, Deltoidospora toralis 
(Leschik) Lund, 1977, Dictyophyllidites mortonii (de Jersey) Playford et Dettmann, 1965,

Duplicisporites granulatus (Leschik) Scheuring, 1970, Gordonispora fossulata (Balme, 1970)

Van Der Eem, 1983, Kraeuselisporites lituus (Leschik) Scheuring, 1974, Lagenella martini

(Leschik) Klaus, 1960, Leptolepidites proxigranulatus (Brenner) Dörhöfer, 1979,

Lycopodiacidites kuepperi Klaus, 1960, Lycopodiacidites rhaeticus Schulz, 1967,

Nevesisporites vallatus de Jersey et Paten, 1964, Ovalipollis pseudoalatus (Thiergart)

Schuurman, 1976, Paracirculina quadruplices Scheuring, 1970, Patinasporites densus

Leschik, 1955, Praecirculina granifer (Leschik) Klaus, 1960, Schizaeoisporites worsleyi

Bjærke et Manum, 1977, Striatella seebergensis Mädler, 1964, Striatella scanica (Nilsson)

Filatoff et Price, 1988, Striatoabieites aytugii (Visscher) Scheuring, 1970, Todisporites

cinctus (Maljavkina) Orlowska-Zwolinska, 1971, Vallasporites ignacii Leschik, 1956,

Vitreisporites pallidus (Reissinger) Nilsson, 1958, Alisporites sp., Aratrisporites sp.,

Calamospora sp., Cycadopites sp., Duplicisporites sp., Ephedripites sp., Todisporites sp., and Verrucosisporites sp.

\subsection{New stratigraphic attribution to the green sandstones}

Starting from $559 \mathrm{~m}$, the distal alluvial fan deposits are well developed with Sh facies underlain by mud clast and coal fragments. This stratigraphic interval is characterised by another retrogradational trend and has been attributed to the Lower Liassic without any biostratigraphic constraint. Only the occurrence of a bioclastic limestone with Gryphaea, starting at a depth of $508.2 \mathrm{~m}$, suggests the Sinemurian stage, because of the regional appearance of this fossil (Lorenz, 1992).

The following taxa were identified for the palynological assemblage SC-4 (Samples PC-46 to PC-54; Fig. 11): Aratrisporites paraspinosus Klaus, 1960, Carnisporites spiniger (Leschik) 
Morbey, 1975, Classopollis meyeriana (Klaus) de Jersey, 1973, Classopollis torosus

(Reissinger) Balme, 1957, Convolutispora klukiforma (Nilsson) Schulz, 1967, Dapcodinium priscum Evitt, 1961, Granulatisporites infirmus (Balme) Cornet et Traverse, 1975,

Kraeuselisporites reissingeri (Harris) Morbey, 1975, Kyrtomisporis speciosus Mädler, 1964, Ovalipollis pseudoalatus (Thiergart) Schuurman, 1976, Paracirculina scurrilis Scheuring, 1970, Patinasporites densus Leschik, 1955, Plaesiodictyon mosellanum Wille, 1970,

Rhaetogonyaulax rhaetica (Sarjeant) Loeblich et Loeblich, 1968, Taurocusporites verrucatus Schulz, 1967, Uvaesporites argenteaeformis (Bolkhovitina) Schulz, 1967, Cibotiumspora sp., Cycadopites sp., Deltoidospora sp., Michrystridium sp., Psophosphaera sp., Uvaesporites sp., and Verrucosisporites sp.

\section{Discussion}

The Sancerre-Couy core can be used to describe the depositional environment of the Permian to Jurassic series. The Permian succession is divided into seven progradationalretrogradational cycles, showing a general evolution from alluvial fan to shallow lake deposits (Fig. 3). Unfortunately, all relevant palynological samples were barren and cannot specify the age of this series, which is considered as Permian (Orszag-Sperber et al., 1992). The Permian succession probably corresponds to the upper Permian based on a seismic line correlation showing similar series further west (Beccaletto et al., 2015).

The Triassic cycles defined from the sedimentary evolution (Fig. 3) have been compared with those of Bourquin et al. (2002) defined from previously published well-log data and sequence stratigraphy (Fig. 12). The SC-1, SC-2 and SC-3 associations correspond to the end of the progradation trend of the major Anisian-Carnian cycle (Bourquin et al., 2006). The SC-1 and SC-2 association (Fig. 3) corresponds to the Ladinian-lower Carnian cycle (Fig. 12), which is 
the lateral equivalent of the Erfurt Fm. in the eastern part of the Paris Basin (Bourquin et al., 2002). The SC-2 and SC-3 associations (Fig. 3) belong to the minor lower-Carnian cycle (Fig. 12), which is a lateral equivalent of the 'Marnes irisées inférieures' Fm. in the eastern part of the basin (Bourquin et al., 2002).

The SC-1 assemblage is Longobardian in age (late Ladinian) due to the presence of Camerosporites secatus, Duplicisporites granulatus, Microcachryidites doubingeri, Ovalipollis pseudoalalus, Paracirculina scurrilis, Porcelispora longdonensis, Triadispora epigona, Triadispora plicata, Triadispora staplinii, and Triadispora falcata. The assemblage presented in our study is equivalent to the "second assemblage" of Adloff et al. (1987). Their assemblage listed the following sporomorphs over the 712.60-710.05 $\mathrm{m}$ interval (unspecified levels): Triadispora aurea, Triadispora suspecta, Triadispora staplinii, Microcachryidites fastidioides, Pytiosporites sp., Alisporites sp., Ovalipollis pseudoalatus, Ovalipollis cultus, and Duplicisporites granulatus. Courel et al. $(1990,1992)$ add Leiotriletes sp. and Porcellispora longdonensis to this list of taxa, and the assemblage was assigned to the late Ladinian due to a correlation with the palynological associations described from the Mâconnais Region, France (Adloff and Doubinger, 1979), Jura Department, France (Adloff et al., 1984), Largentière Basin, Ardèche, France (Doubinger and Adloff, 1977), and the Monte San Giorgio, Southern Alps, Switzerland (Scheuring, 1978). The SC-1 assemblage corresponds in age to the Camerosporites secatus-Enzonalasporites vigens phase (Van der Eem, 1983), the Heliosaccus dimorphus zone from Orłowska-Zwolińska (1983, 1985, 1988) and Kürschner and Herngreen (2010), and the TrS-F Zone (Protrachyceras archelausFrankites regoledanus Zone) from Hochuli et al. (2015).

The SC-2 assemblage is dated as Longobardian-Cordevolian transition to early Carnian (Ladinian-Carnian transition) in age due to the presence of Ladinian-Carnian sporomorphs such as Camerosporites secatus, Duplicisporites granulatus, Ovalipollis pseudoalatus, 
Microcachryidites doubingeri, Porcellispora longdonensis, and the occurrence of the typical Carnian taxa Paracirculina quadruplicis, Patinasporites densus and Vallasporites ignacii. The late Ladinian-Carnian period is characterised by a rapid diversification of Circumpollen taxa such as Camerosporites secatus, Duplicisporites granulatus and Praecirculina granifer, in association with the appearance of Patinasporites densus, Samaropollenites speciosus, and Vallasporites ignacii (Schuurman's phase I; Visscher and Krystyn, 1978; Visscher and Brugman, 1981; Van der Eem, 1983; Brugman et al., 1994; Roghi, 2004; Cirilli, 2010; Kürschner and Herngreen, 2010). The first appearance of Patinasporites densus corresponds to the base of the early Carnian Enzonalasporites vigens-Patinasporites densus phase of Van der Eem (1983) and is associated with the first appearance of Vallasporites ignacii (Visscher and Brugman, 1981; Van der Eem, 1983; Fisher and Dunay, 1984; Blendinger, 1988; Hochuli et al., 1989; Hochuli and Frank, 2000; Roghi, 2004; Cirilli, 2010; Kürschner and Herngreen, 2010). SC-2 corresponds to the "first assemblage" of Adloff et al. (1987), collected from the 699.45-697.45 m interval (unspecified levels), and composed of Ovalipollis pseudoalatus, Vallasporites ignacii, Camerosporites secatus, Paracirculina quadruplicis, and Patinasporites densus. Adloff et al. (1987) compare their assemblage with the Jura borehole assemblages (association A5; Adloff et al., 1984) and the ammonite levels of the Austrian Alps (Dunay and Fisher, 1978), attributing it a Carnian age.

The SC-3 assemblage is Cordevolian in age due to the co-occurrence of Aulisporites astigmosus and Lagenella martini - with a range restricted to the Cordevolian-early Tuvalian - together with typical late Ladinian-Carnian palynomorphs such as Camerosporites secatus and Duplicisporites granulatus, and the Carnian taxa Anapiculatisporites spiniger, Brodispora striata, Cibotiumspora juriensis, Kraeuselisporites lituus, Lycopodiacidites kuepperi, Paracirculina quadruplicis, Patinasporites densus, and Vallasporites ignacii. Lagenella martinii is known from an ammonoid-controlled succession of the Raibl Group, 
Southern Alps, and has been recorded in Europe starting from the Cordevolian (Van der Eem, 1983) and from the Cordevolian to the early Tuvalian (Visscher and Brugman, 1981; Litwin et al., 1991; Hochuli and Frank, 2000; Roghi, 2004; Medhi et al., 2009; Roghi et al., 2010). Additionally, Aulisporites astigmosus is characteristic of the early Carnian palynological assemblages (Dunay and Fisher, 1978; Orłowska-Zwolińska, 1983; Hochuli, 1998;

Fijałkowska-Mader, 1999; Kirichkova and Kulikova, 2005; Medhi et al., 2009, FijałkowskaMader, 1999). The co-occurrence of Lagenella martinii and Aulisporites astigmosus have been described from the Dupliciporites continuus assemblage of the Conzen and Tor Fm. (Roghi, 2004), as well as the early Carnian Tr3 (Black Dolostones) and Tr4 (Middle Gypsum) units of the Rheouis Fm. (Medhi et al., 2009). The association is also comparable with those of the Astigmosus zone, described in Poland (Orłowska-Zwolińska, 1983; FijałkowskaMader, 1999) and from European epicontinental areas (Dunay and Fisher, 1978; Brugman, 1983; Medhi et al., 2009). Moreover, this association is present in many other parts of Europe related with the Carnian Pluvial Event which determined a humid climatic perturbation over a large area of the Northern Hemisphere (Roghi et al., 2010).

The SC-4 assemblage is late Rhaetian in age due to the presence of Carnisporites spiniger, Classopollis meyeriana, Convolutispora klukiforma, Kraeuselisporites (= Heliosporites) reissingeri, Ovalipollis pseudoalatus and Taurocusporites verrucatus, as well as the dinoflagellates Dapcodinium priscum and Rhaetogonyalax rhaetica. Taxonomically, this assemblage is similar to the one shown in the upper part of the Lower Member (middle Rhaetian) in the Rhaetian Fm. of the Lodève Basin, France (Courtinat and Piriou, 2002). It resembles the RG Subzone (Rhaetian) in the Kendelbachgraben section, Austria (Morbey and Neves, 1974), and the B association (upper part of the early Rhaetian) from Adloff and Doubinger (1982). Assemblage SC-4 is located at stratigraphical levels (559-553 m) equivalent to the base of the 555.8-515.80 m interval studied in Lorenz et al. (1978) as 
homogeneous residue. Their work yielded a rich assemblage including Classopollis spp., Heliosporites reissingeri, Deltoidospora toralis, Taurocusporites verrucatus, Alisporites robustus, and Dapcodinium priscum. To propose an age, they use the debatable "criterion of absence" with the palynomorphs Ovalipollis pseudoalatus, Rhaetipollis germanicus, and Cerebropollenites pseudomassulae, inferring that these samples are found in the basal part of the Hettangian. However, Taugourdeau (in Lorenz et al., 1987) provides evidence for the possibility of carrying out a more precise study as Rhaetian material may be found at the bottom of this interval. Later, Lorenz (1992) discarded this hypothesis and shortened the palynological interval to $555.25-542.55 \mathrm{~m}$.

The high prevalence of Classopollis spp. together with Carnisporites spiniger, Deltoidospora spp., Kraeuselisporites (= Heliosporites) reissingeri, and Ovalipollis pseudoalatus, together with the occurrence of the dinoflagellates Dapcodinium priscum and Rhaetogonyalax rhaetica, is observed in the SAB3 zone from the upper part of the Lilstock Fm., St. Audrie's Bay (Bonis et al., 2010; Lindström 2016; Lindström et al., 2017). The SAB3 zone (Bonis et al., 2010) is considered to represent the "recovery flora" during the end-Triassic event (Lindström, 2016). The last appearance of Ovalipollis pseudoalatus together with the first appearance of Kraeuselisporites (= Heliosporites) reissingeri in some parts of Europe (Hochalplgraben, Austria: Bonis et al., 2009; St Audrie's Bay, United Kingdom: Bonis et al., 2010; Kuhjoch, Austria: Hillebrandt et al., 2013; Stenlille, Denmark: Lindström, 2016; Lindström et al., 2017) may be characteristic of this late Rhaetian event.

The coexistence of the microplankton Dapcodinium priscum and Rhaetogonyalax rhaetica has been also recorded in other studies: in the Kendelbachgraben section, Austria (Rhaetian age; Morbey and Neves, 1974), the Brigadier Fm. in the North West Shelf of Australia (Backhouse et al., 2002), the Rhaetian Fm. of the Lodève Basin, France (middle Rhaetian; Courtinat and Piriou, 2002), the Northern Calcareous Alps, Austria (latest Rhaetian in 
Kürschner et al., 2007; late Rhaetian and lowermost Jurassic in Bonis et al., 2009).

A retrogradational cycle at the end of the Triassic series is mentioned in other works such as Bonis et al. (2010), Lindström (2016), and Lindström et al. (2017). The palynomorph-based late Rhaetian age is characterised by a regressive event in the Lilstock Fm. (St. Audrie's Bay, United Kingdom; Bonis et al., 2010), grey siltstone interval (Stenlille, Denmark; Lindström, 2016), Triletes beds (Rødby, Denmark: Lund, 1977; Mingolsheim, Germany: Van de Schootbrugge et al., 2008; Mariental, Germany: Heunisch et al., 2010; Schandelah, Germany: Lindström et al., 2015), and Schattwald beds (Kuhjoch, Northern Calcareous Alps, Austria; Hillebrandt et al., 2013).

Until now, the Rhaetian-Hettangian boundary could not be precisely established in the Sancerre-Couy- 1 core as there have been no new paleontological data. Taking into account that Gely and Lorenz (1991) located the Hettangian-Sinemurian boundary at $508.20 \mathrm{~m}$, and assuming that the age is late Rhaetian at $553 \mathrm{~m}$, the Rhaetian-Hettangian limit should be located in the lower part of the interval between 553 and $508.2 \mathrm{~m}$. However, based on welllog correlation data, the Triassic-Jurassic boundary has been located at $548.5 \mathrm{~m}$ (Fig. 2); these sandstone deposits, attributed to the Rhaetian, were previously described in Hamon and Merzeraud (2005).

\section{Conclusions}

Based on a core analysis, high-resolution sequence stratigraphy of the Permian and Triassic series of the southwestern Paris Basin is used to distinguish seven progradationalretrogradational cycles for the Permian and twelve cycles for the Triassic. For the first time, the classical palynological assemblages defined for the Sancerre-Couy-1 core have been found, re-studied and illustrated. The associations are clearly more complete than those 
presented by Courel et al. (1990) and Lorenz (1992). The new records allow: (i) a better definition of the age of two assemblages (lower and upper, equivalent to PC-1 and PC-2); (ii) the definition of a new palynostratigraphic assemblage (PC-3), belonging to the 698.45$697.45 \mathrm{~m}$ interval; and (iii) the reinterpretation of the 559.25-553 m levels (PC-4; Lorenz et al. 1992) previously attributed to the Hettangian (Early Jurassic).

The different ages attributed for some cycles in our study confirm the hypothesis given in Bourquin et al. (2002). The PC-1, PC-2 and PC-3 palynological associations correspond to the end of the progradation trend for the major Anisian-Carnian cycle (Bourquin et al., 2006). The PC-1 and PC-2 association corresponds to the Ladinian-lower Carnian cycle, which is the lateral equivalent of the Erfurt Fm. in the eastern part of the Paris Basin (Bourquin et al., 2002). The PC-2 and PC-3 association corresponds to the minor lower-Carnian cycle, which is a lateral equivalent of the 'Marnes irisées inférieures' Fm. in the eastern part of the basin (Bourquin et al., 2002). The PC-4 assemblage suggests a late Rhaetian age and corresponds to the SAB3 zone which is considered to represent the "recovery flora" during the end-Triassic event (Lindström, 2016). Consequently, the Rhaetian-Hettangian boundary in the SancerreCouy-1 core should be located in the lower part of the interval between 553 and $508.2 \mathrm{~m}$ based on the paleontological data. Based on well-log correlations, the Triassic-Liassic boundary has been located at $548.5 \mathrm{~m}$.

Finally, these sedimentological and palynological high-resolution results from the SancerreCouy core establish a new reference section for the Permian to Triassic deposits of the Paris Basin. The present work will be of great help in further correlations with neighbouring Permian and Triassic outcrops or core-free borehole.

Acknowledgements 
The authors are grateful to Dr. Evelyn Kustatscher and an anonymous reviewer for helpful and constructive suggestions, and to the editor Dr. Borja Cascales-Miñana for his valuable recommendations. This research was supported by the CGL2014-52699P (Spanish Ministry) and GRC 2015/020 projects (Xunta de Galicia).

\section{References}

Adloff, M.C., Doubinger, J., 1979. Étude palynologique dans le Mésozoïque de base de la bordure NE du Massif Central français. 7ème réunion annuelle des Sciences de la terre, Lyon 1979, Société géologique de France, 1.

Adloff M.C., Doubinger J., 1982. Étude palynologique du Rhétien et de l'Hettangien de cinq sondages situés dans les environs de Mersch (Luxembourg). Bulletin d'information des géologues du bassin de Paris 19(2), 9-20.

Adloff, M.C., Appia, C., Doubinger, J., Lienhardt, M.J., 1984. Zonations palynostratigraphiques dans les séries triasiques traversées par les sondages dans le Jura et le Bas-Dauphiné. Géologie de la France 1-2, 3-21.

Adloff, M.C., Courel, L., Giot, D., Lacombe, P., Marteau, P., 1987. Le Trias, Documents du BRGM 136, 27-30.

Adloff, M.C., Courel, L., Doubinger, J., Giot, D., Lacombe, P., Marteau, P., 1992. Le Trias du forage de Sancerre-Couy: la trangression triasique est le témoin d'un haut niveau marin ladinien. Géologie de la France 3-4, 51-56.

Autran, A., Lefort, J.P., Debeglia, N., Edel, J.B., Vigneresse, J.L., 1994. Gravity and magnetic expression of terranes in France and their correlation beneath overstep sequences, in: Keppie, J.D. (Ed.), Pre-Mesozoic Geology in France and related areas. Springer, Berlin, pp. 49-72. 
Backhouse J., Balme B.E., Helby R., Marshall N.G., Morgan R., 2002. Palynological zonation and correlation of the latest Triassic, Northern Carnarvon Basin, in: Keep M., Moss S.J. (Eds.), the sedimentary basins of Western Australia 3. Proceedings of the Petroleum Exploration Society of Australia Symposium, Perth, WA, pp. 179-194.

Beccaletto, L., Capar, L., Serrano, O., Marc, S., 2015. Structural evolution and sedimentary record of the Stephano-Permian basins occurring beneath the Mesozoic sedimentary cover in the southwestern Paris basin (France). Bulletin de la Société Géologique de France 6, 429450.

Blair, T.C., Mcpherson, J.G., 1994. Alluvial fan processes and forms, in: Abrahams, A.D., Parsons, A.J. (Eds), Geomorphology of Desert Environments. Chapman \& Hall, London, pp. $354-402$.

Blendinger, E., 1988. Palynostratigraphy of the late Ladinian and Carnian in the Southeastern Dolomites. Review of Palaeobotany and Palynology 53, 329-348.

Bonis, N.R., Kürschner, W.M., Krystyn, L., 2009. A detailed palynological study of the Triassic-Jurassic transition in key sections of the Eiberg Basin (Northern Calcareous Alps, Austria). Review of Palaeobotany and Palynology 156, 376-400.

Bonis, N.R., Ruhl, M., Kürschner, W.M., 2010. Milankovitch-scale palynological turnover across the Triassic-Jurassic transition at St. Audrie's Bay, SW UK. Journal of the Geological Society $167,877-888$.

Bourquin, S., Guillocheau, F., 1993. Géométrie des séquences de dépôt du Keuper (Ladinien à Rhétien) du Bassin de Paris: Implications géodynamiques. Comptes Rendus de l'Académie des Sciences de Paris 217, 1341-1348.

Bourquin, S., Friedenberg, R., Guillocheau, F., 1995. High-resolution sequence stratigraphy 
in the Triassic series of the Paris Basin: geodynamic implications. Cuadernos de Geología Ibérica 19, 337-362.

Bourquin S., Guillocheau, F., 1996. Keuper stratigraphic cycles in the Paris Basin and comparison with cycles in other Peritethyan basins (German Basin and Bresse-Jura Basin). Sedimentary Geology 105, 159-182.

Bourquin S., Rigollet C., Bourges P., 1998. High-resolution sequence stratigraphy of an alluvial fan - fan delta environment: stratigraphic and geodynamic implications - Example of the Chaunoy Sandstones, Keuper of the Paris Basin. Sedimentary Geology 121, 207-237. Bourquin, S., Robin, C., Guillocheau, F., Gaulier, J.M., 2002. Three-dimensional accommodation analysis of the Keuper of the Paris Basin: discrimination between tectonics, eustasy, and sediment supply in the stratigraphic record. Marine and Petroleum Geology 19, 469-498.

Bourquin S., Peron S., Durand M., 2006. Lower Triassic sequence stratigraphy of the western part of the Germanic Basin (west of Black Forest): fluvial system evolution through time and space. Sedimentary Geology 186, 187-211.

Bourquin S., Bercovici A., López-Gómez J, Diez J.B., Broutin J., Ronchi A., Durand M., Arche A., Linol B., Amour F., 2011. The Permian-Triassic transition and the beginning of the Mesozoic sedimentation at the Western peri-Tethyan domain scale: palaeogeographic maps and geodynamic implications. Palaeogeography, Palaeoclimatology, Palaeoecology 299, 265280.

BRGM (2003). Carte géologique de la France au 1/1 $000000^{\text {ème }}, 6^{\text {ème }}$ édition révisée.

Brugman, W.A., 1983. Permian-Triassic palynology. Laboratory of Palaeobotany and Palynology, University of Utrecht, 122 p. 
Brugman, W.A., Van Bergen, P.F., Karp, J.H.F., 1994. A quantitative approach to Triassic palynology, in: Traverse, A. (ed.), Sedimentation of organic particles. Cambridge University Press, Cambridge, pp. 409-429.

Burg J.P., Van Den Driessche J., Brun J.P., 1994. Syn- to post- thickening extension in the Variscan Belt of Western Europe: modes and structural consequences. Géologie de la France $3,33-51$.

Chantraine, J., Lorenz, C., Mégnien, C., Million, R., Lienhardt, M.J., 1992. Forage scientifique de Sancerre-Couy (Cher): Synthèse d'études 1986-1992. Mémoire du Bureau de Recherches Géologiques et Minières, Géologie Profonde de la France 3, 230 p.

1992. Forage scientifique de Sancerre-Couy - Terrain sédimentaires, socle et anomalie magnétique du bassin de Paris. Géologie de la France, BRGM ed., 3-4.

Cirilli, S., 2010. Upper Triassic-lowermost Jurassic palynology and palynostratigraphy: a review, in: Lucas, S.G. (Ed.), The Triassic Timescale. Geological Society, London, Special Publications, 334, pp. 285-314.

Costa, S., Maluski, H., 1988. Datation par la méthode Ar-Ar de matériel magmatique et métamorphique paléozoïque provenant du forage de Couy-Sancerre (Programme GPF). Comptes Rendus de l'Académie des Sciences de Paris, D 306, 241-244.

Courel, L., Adloff, M.C., Doubinger, J., Lacombe, P.,1990. La transgression triasique en France centrale; témoin d'un haut niveau marin ladinien; données nouvelles du sondage de Sancerre-Couy (Cher, France). Bulletin de la Société géologique de France 8, VI, 5, 723-729. Courel, L., Bourquin, S., Jaquin, T., Vannier, F., 1992. Sequence Stratigraphy of the Triassic series on the western Peri-Tethyan margin (France, Switzerland). Abstracts of the International Symposium "Mesozoic and Cenozoic sequence stratigraphy of European 
basins", Dijon, France, pp. 120-121.

Courtinat, B., Piriou, S., 2002. Les palynomorphes du Rhétien du bassin de Lodève : stratigraphie et environnements de dépôts. Géologie de la France 3, 3-16.

Delmas, J., Houel, P., Vially, R., 2002. Paris Basin, Petroleum potential. IFP regional report. Doubinger, J., Adloff, M.C., 1977. Études palynologiques dans le Trias de la bordure sud-est du Massif central français (bassin de Largentiere, Ardèche). Sciences Géologiques 30(1), 5974.

Dunay, R.E., Fisher, M.J., 1978. The Karnian palynoflora succession in the Northern Calcareous Alps, Lunz am See, Austria. Pollen et Spores 20, 177-187.

Echtler, H., Malavieille, J., 1990. Extensional tectonics, basement uplift and StephanoPermian collapse basin in a late Variscan metamorphic core complex (Montagne Noire, southern Massif Central). Tectonophysics 177, 125-138.

Fijałkowska-Mader, A., 1999. Palynostratigraphy, palaeoecology and palaeoclimatology of the Triassic in south-eastern Poland. Zentralblatt für Geologie und Paläontologie 1, 601-627. Fisher, M.J., Dunay, R.E., 1984. Palynology of the Petrified Forest Member of the Chinle Formation (Upper Triassic), Arizona, USA. Pollen et Spores 26, 241-284.

Gely, J.P., Lorenz, J., 1991. Analyse séquentielle du Jurassique du forage de Couy. Comptes Rendus de l'Académie des Sciences de Paris 313, 247-353.

Guillocheau, F., Robin, C., Allemand, P., Bourquin, S., Brault, N., Dromart, G., Friedenberg, R., Garcia, J.P., Gaulier, J.M, Gaumet, F., Grosdoy B., Manot, F., Le Strat, P., Mettraux, M. Nalpas, T., Prijac, P., Rigollet C., Serrano, O., Grandjean, G., 2000. Meso-cenozoic geodynamic evolution of the Paris Basin: 3D stratigraphic constraints. Geodinamica Acta 13, 189-246. 
Hamon, Y., Merzeraud, G., 2005. Nouvelles données sur le Trias de Sologne (Chémery, sudouest du bassin de Paris) : stratigraphie et environnements de dépôts: Géologie de la France 1, $3-22$.

Hasiotis, S.T., 2006. Continental trace fossils. Society of Economic Paleontologists and Mineralogists Short Course 51, 132 p.

Hasiotis, S.T., Kraus, M.J., Demko, T.M., 2007. Climatic controls on continental track fossils, in: Miller, W. (Ed.), Trace Fossils Concepts, Problems, Prospects. Elsevier, Berlin, pp. 172195.

Heunisch, C., Luppold, F.W., Reinhardt, L., Röhling, H.G., 2010. Palynofazies, Bio- und Lithostratigraphie im Grenzbereich Trias/Jura in der Bohrung Mariental 1 (Lappwaldmulde, Ostniedersachsen). Zeitschrift der Deutschen Gesellschaft für Geowissenschaften 161, 51-98.

Hillebrandt, A.V., Krystyn, L., Kürschner, W.M., Bonis, N.R., Ruhl, M., Richoz, S., Schobben, M.A.N., Urlichs, M., Bown, P.R., Kment, K., McRoberts, C.A., Simms, M., Tomãsových, A., 2013. The Global Stratotype Sections and Point (GSSP) for the Base of the Jurassic System at Kuhjoch (Karwendel Mountains, Northern Calcareous Alps, Tyrol, Austria). Episodes 36, 162-198.

Hochuli, P.A., 1998. Spore-pollen, in: Hardenbol, J., Thierry, J., Farley, M.B., Jacquin, T., de Graciansky, P.C., Vail, P.R. (Eds.), Mesozoic and Cenozoic sequence chronostratigraphic framework of European basins. SEPM Special Publication 60, Chart 8.

Hochuli, P.A., Colin, J.P., Vigran, J., 1989. Triassic biostratigraphy of the Barents Sea area, in: Collins, J.D. (Ed.), Correlation in Hydrocarbon Exploration. Norwegian Petroleum Society, Graham and Trotman Ltd., Oslo, pp. 131-153.

Hochuli, P.A., Frank, S.M., 2000. Palynology (dinoflagellate cysts, spore-pollen) and 
stratigraphy of the Lower Carnian Raibl Group in the Eastern Swiss Alps. Eclogae Geologicae Helvetiae 93, 429-443.

Hochuli, P.A., Roghi, G., Brack, P., 2015. Palynological zonation and particulate organic matter of the Middle Triassic of the Southern Alps (Seceda and Val Gola-Margon sections, Northern Italy). Review of Palaeobotany and Palynology 218, 28-47.

Kirichkova, A.I., Kulikova, N.K., 2005. The problem of correlation between Triassic continental sequences of Southern Germany, the Timan-Pechora region and Eastern Urals. Stratigraphy and Geological Correlation 13, 416-429 (Translated from Stratigrafiya. Geologicheskaya Korrelyatsiya 13 (4), 86-100).

Kürschner, W., Waldemaar Herngreen, G.F., 2010. Triassic palynology of central and northwestern Europe: a review of palynofloral diversity patterns and biostratigraphic subdivisions, in: Lucas, S.G. (Ed.), The Triassic Timescale. Geological Society, London, Special Publications 334, pp. 263-283.

Kürschner, W.M., Bonis, N.R., Krystyn, L., 2007. Carbon-isotope stratigraphy and palynostratigraphy of the Triassic-Jurassic transition in the Tiefengraben-section Northern Calcareous Alps (Austria). Palaeogeography, Palaeoclimatology, Palaeoecology 244, 257280.

Lindström, S., 2016. Palynofloral patterns of terrestrial ecosystem change during the endTriassic event - a review. Geological Magazine 153, 223-251.

Lindström, S., Pedersen, G.K., van de Schootbrugge, B., Hansen, K.H., Kuhlmann, N., Thein, J., Johansson, L., Petersen, H.I., Alwmark, C., Dybkjær, K., Weibel, R., Erlström, M., Nielsen, L.H., Oschmann,W., Tegner, C., 2015. Intense and widespread seismicity during the end-Triassic mass extinction due to emplacement of a large igneous province. Geology 43, 387-390. 
Lindström, S., van de Schootbrugge, B., Hansen, K.H., Pedersen, G.K., Alsen, P., Thibault, N., Dybkjær, K., Bjerrum, C.J., Nielsen, L.H., 2017. A new correlation of Triassic-Jurassic boundary successions in NW Europe, Nevada and Peru, and the Central Atlantic Magmatic Province: A time-line for the end-Triassic mass extinction. Palaeogeography, Palaeoclimatology, Palaeoecology 478, 80-102.

Litwin, R.J., Traverse, A., Ash, S.R., 1991. Preliminary palynological zonation of the Chinle Formation, southwestern USA, and its correlation to the Newark Supergroup (eastern USA). Review of Palaeobotany and Palynology 68, 269-287.

Lorenz J., 1992. Le Jurassique du forage de Sancerre-Couy. L'invasion marine. Géologie de la France 3-4, 61-75.

Lorenz, J., Lefavrais, A., Depeche, F., Leclerc, V., Marchand, D., Roy, B., Taugourdeau, J., Reyre, Y., 1987. Le Jurassique. Documents du BRGM 136, 19-30.

Lowe, D.R., 1982. Sediment gravity flows: II. Depositional models with special reference to the deposits of high-density turbidity currents. Journal of Sedimentary Petrology 52, 279-297.

Lund, J.J., 1977. Rhaetic to Lower Liassic palynology of the onshore south-eastern North Sea Basin. Danmarks Geologiske Undersugelse II (109), 1-129.

Marteau, P., 1983. Le bassin permo-carbonifêre d'Autun; Stratigraphie, sédimentologie et aspects structuraux. Documents du BRGM 64, 198 p.

Mascle, A., 1990. Géologie pétrolière des basins permiens français. Comparaison avec les bassins permiens du Nord de l'Europe. Chronique de la recherche minière 499, 69-86.

Mégnien, C., 1980. Tectonogenèse du Bassin de Paris: étapes de l'évolution du bassin. Bulletin de la Société géologique de France 22, 669-680.

Mehdi, D., Cirilli, S., Buratti, N., Kamoun, F., Trigui, A., 2009. Palynological 
characterisation of the Lower Carnian of the Kea5 borehole (Koudiat El Halfa Dome; Central Atlas, Tunisia). Geobios 42, 63-71.

Miall, A.D., 1996. The Geology of Fluvial Deposits. Springer, Berlin, 582 p.

Morbey, S.L., Neves, R., 1974. A scheme of palynologically defined concurrent-range zones and subzones for the Triassic Rhaetian Stage (sensu lato). Review of Palaeobotany and Palynology 17, 161-173.

Mulder, T., Alexander, J., 2001. The physical character of subaqueous sedimentary density flows and their deposits. Sedimentology 48, 269-299.

Orłowka-Zwolińska, T., 1983. Palynostratigraphy of the upper part of Triassic Epicontinental sediments in Poland. Prace Instytutu Geologicznego, Wydawnictwa Geologiczne 104, 1-89.

Orłowka-Zwolińska, T., 1985. Palynological zones of the Polish epicontinental Triassic.

Bulletin of the Polish Academy of Science, Earth Sciences 33(3-4), 107-117.

Orłowka-Zwolińska, T., 1988. Palynostratigraphy of Triassic deposits in the vicinity of Brzeg (SE part of the Fore-Sudetic Monocline). Kwartalnik Geologiczny 32, 349-366.

Orszag-Sperber, F., Freytet, P., Lebreton, M.L., 1992. Le Permien du forage de Couy: dépôts de plaine d'inondation, in: Forage scientifique de Sancerre-Couy (Cher): Synthèse d'études 1986-1992. Mémoire Géologie Profonde de la France 3, 43-49.

Paquette, Y., Feys, R., 1989. Le bassin de Bourbon l'Archambault. Synthèse géologique des bassins permiens français. Mémoires du BRGM 128, 43-54.

Pellenard, P., Gand, G., Schmitz, M., Galtier, J., Broutin, J., Stéyer, J.-S., 2017. Highprecision $\mathrm{U}-\mathrm{Pb}$ zircon ages for explosive volcanism calibrating the NW European continental Autunian stratotype. Gondwana Research 51, 118-136. 
Perrodon, A., Zabeck, J., 1990. Paris Basin. Interior Cratonic Basins, in: Leighton, M.W., Kolata, D.R., Oltz, D.F., Eidel, J.J. (Eds.), AAPG Memory 51, pp. 633-679.

Postma, G., 1990. Depositional architecture and facies of river and fan deltas: a synthesis, in:

Colella, A., Prior, D.B. (Eds.), Coarse grained Deltas. International Association of

Sedimentologists, Special Publication, vol. 10, 13-27.

Praeg, D., 2004. Diachronous Variscan late-orogenic collapse as a response to multiple detachments; a view from the internides in France to the foreland in the Irish Sea. Geological Society Special Publications 223, pp. 89-138.

Roger, J., Gaudry, F., Marteau, P., Quesnel, F., Chèvremont, P., Jauffret, D., 2010. Notice explicative, Carte géologique de la France (1/50 000), feuille Decize (549). Orléans: BRGM, 185 p. Carte géologique par Gaudry F., Roger J., Marteau P., Quesnel F., Chèvremont P. (2010).

Roghi, G. 2004. Palynological investigations in the Carnian of the Cave del Predil area (Julian Alps, NE Italy). Review of Palaeobotany and Palynology 132, 1-35.

Roghi, G., Gianolla, P., Minarelli, L., Pilati, C., Preto, N., 2010. Palynological correlation of Carnian humid pulses throughout western Tethys: Palaeogeography, Palaeoclimatology, Palaeoecology 290, 89-106.

Scheuring, B., 1978. Mikrofloren aus den Meridelkalken des Monte San Giorgio (Kanton Tessin). Abhandlungen der Schweizerischen Paläontologischen Gesellschaft 100, 1-205.

Valle, B., 1986. Evolution structurale du fossé stephano-permien de Blanzy (Massif Central, France) depuis la fin du Carbonifère; implications tectoniques régionales. Comptes Rendus de l'Académie des Sciences, Sér.2 302, 593-598.

Van de Schootbrugge, B., Payne, J.L., Tomasovych, A., Pross, J., Fiebig, J., Benbrahim, M., 
Föllmi, K.R., Quan, T.M., 2008. Carbon cycle perturbation and stabilization in the wake of the Triassic-Jurassic boundary mass extinction event. Geochemistry, Geophysics, Geosystems 9, Q04028.

Van Der Eem, J.G.L.A., 1983. Aspects of Middle and Late Triassic Palynology: 6.

Palynological investigations in the Ladinian and Lower Karnian of the Western Dolomites, Italy. Review of Palaeobotany and Palynology 39, 189-300.

Visscher, H., Krystyn, L., 1978. Aspects of Late Triassic palynology. 4. A palynological assemblage from ammonoid-controlled late Karnian (Tuvalian) sediments of Sicily. Review of Palaeobotany and Palynology 26, 93-112.

Visscher, H., Brugman, W., 1981. Ranges of selected palynomorphs in the Alpine Triassic of Europe. Review of Palaeobotany and Palynology 34, 115-128.

Table and Figure captions 


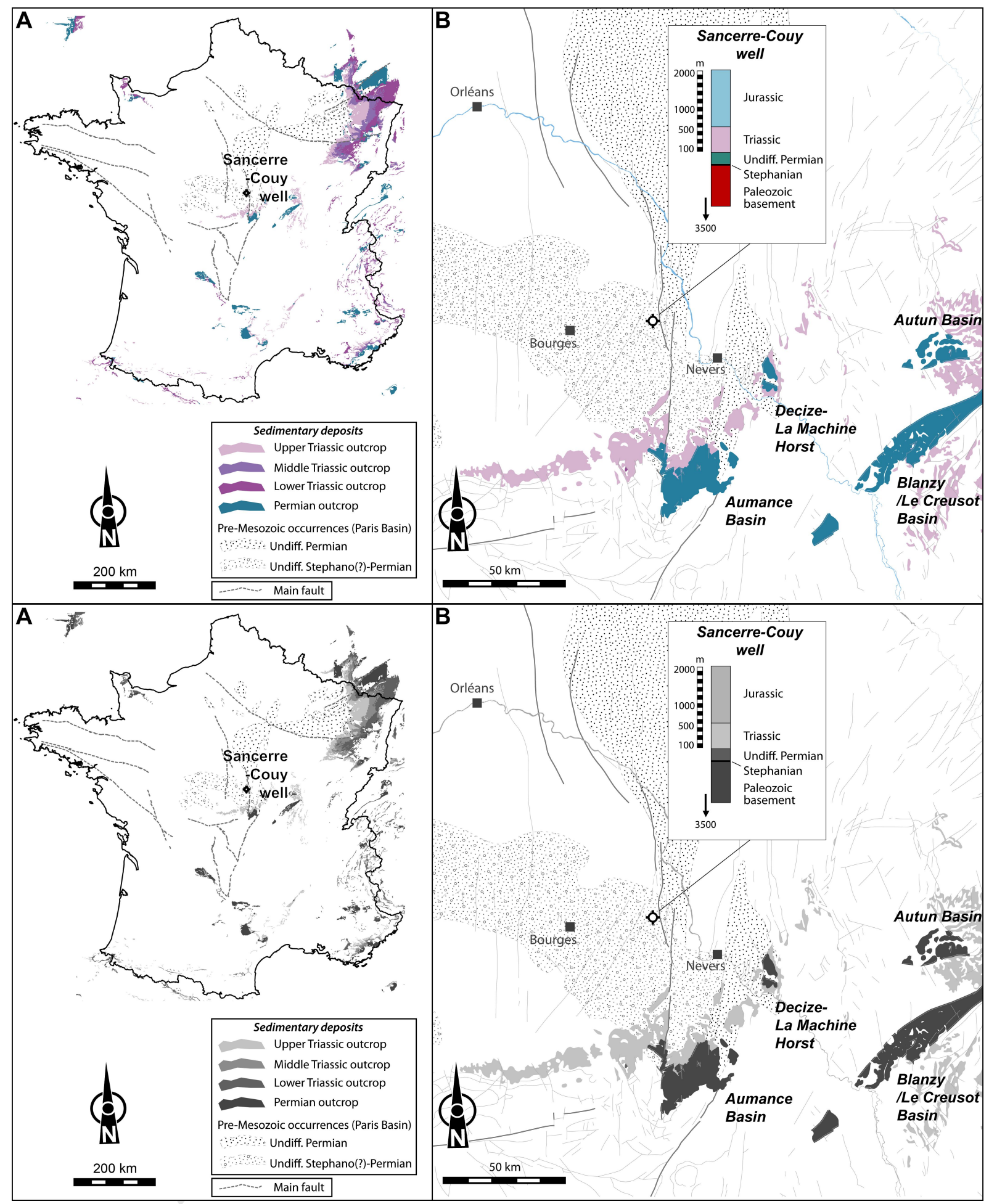

Figure 1 A. Triassic and Permian outcrops and geological background in France, taken from the 1:1,000,000 geological map of France (BRGM, 2003). B. Location map of the SancerreCouy well. 
Sancerre-Couy well

(Permian to base Jurassic section)

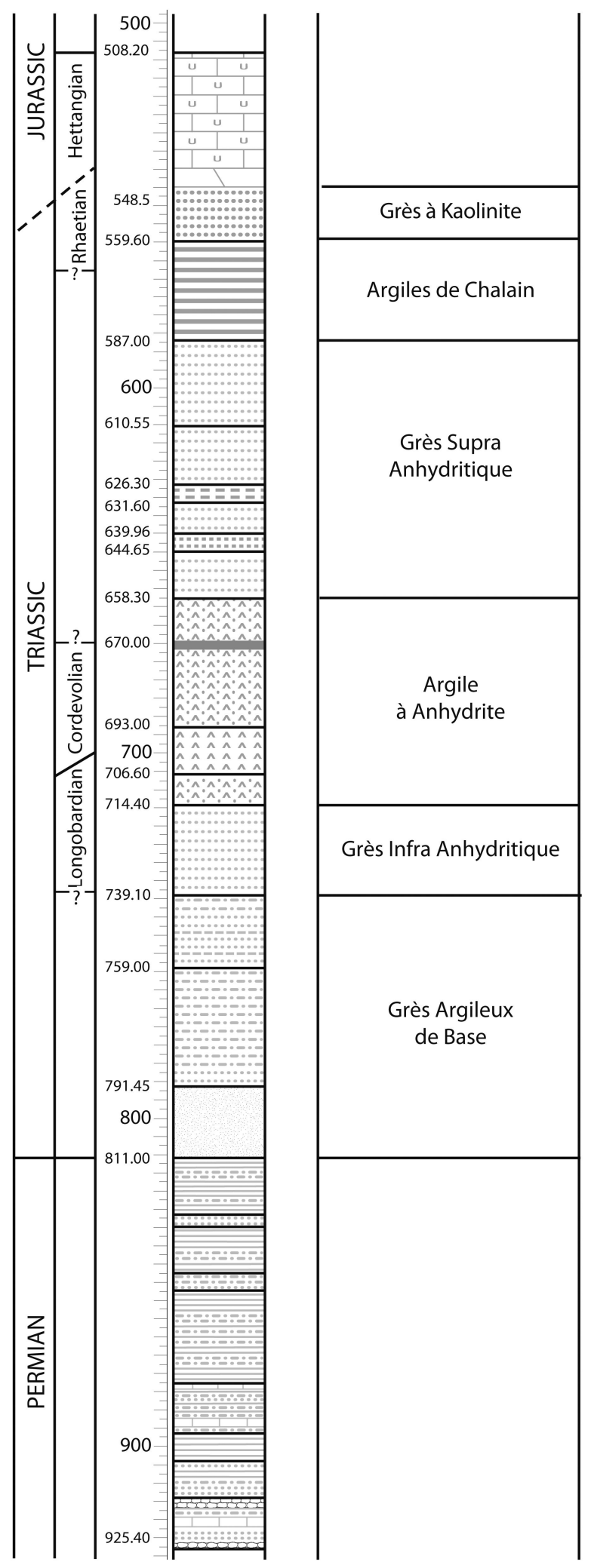

Figure 2 Simplified sedimentary column of the Permian-Triassic-lower Jurassic deposits from the Sancerre-Couy core. 


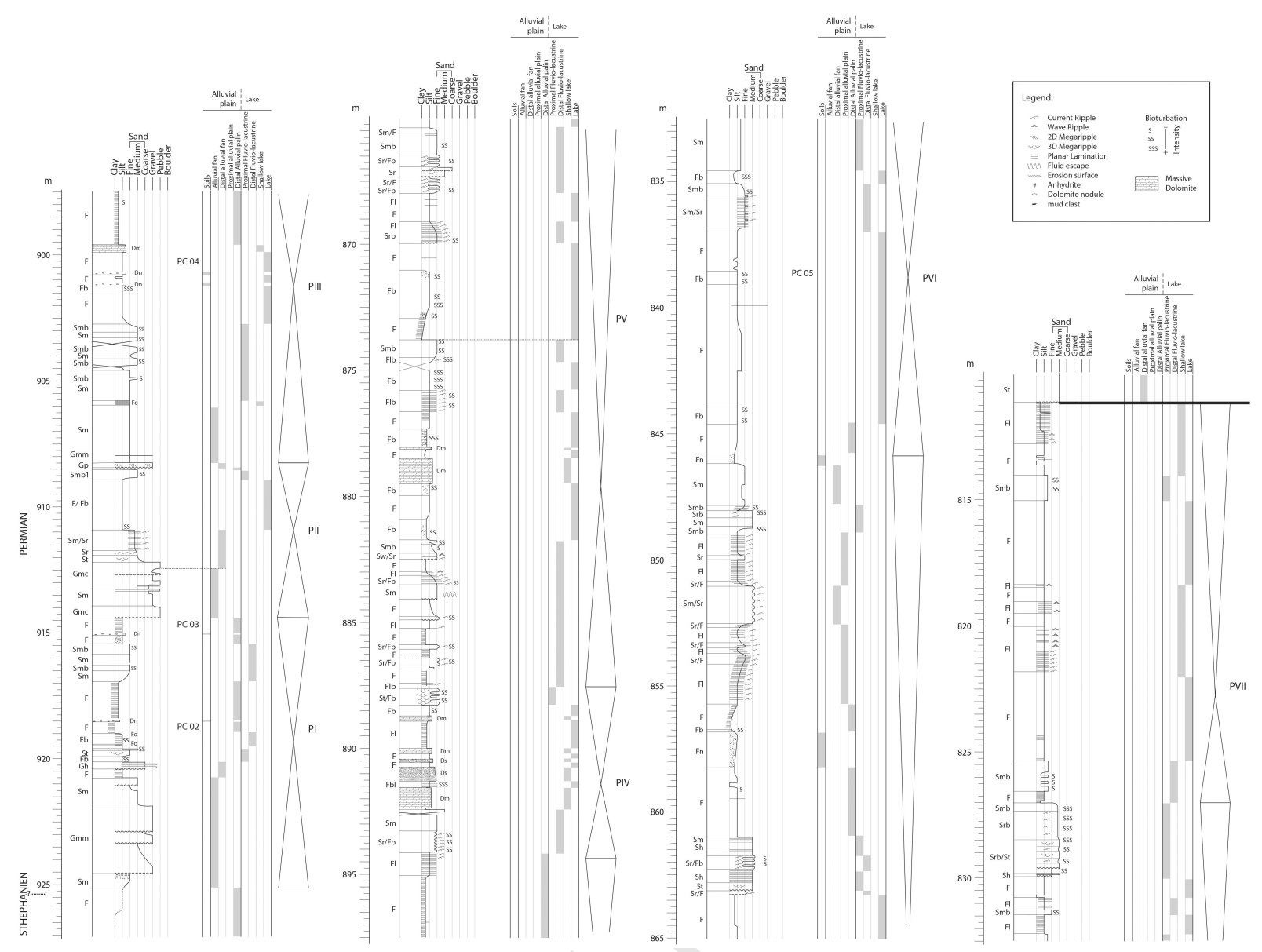

Figure 3 Sedimentological section, depositional environment evolution and stratigraphic cycles for the Sancere-Couy core during the Permian. 


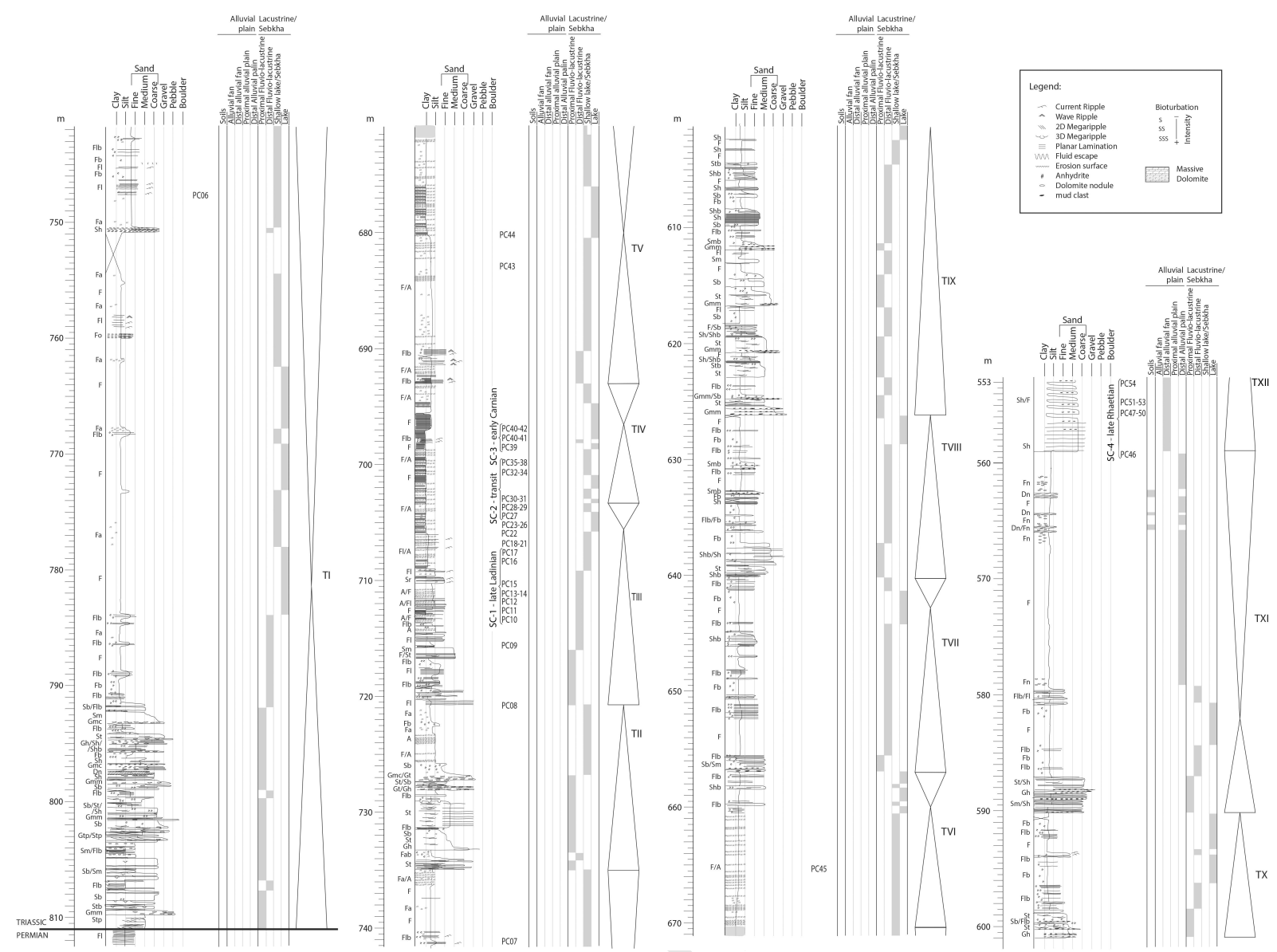

Figure 4 Sedimentological section, depositional environment evolution and stratigraphic cycles for the Sancere-Couy core during the Triassic. 


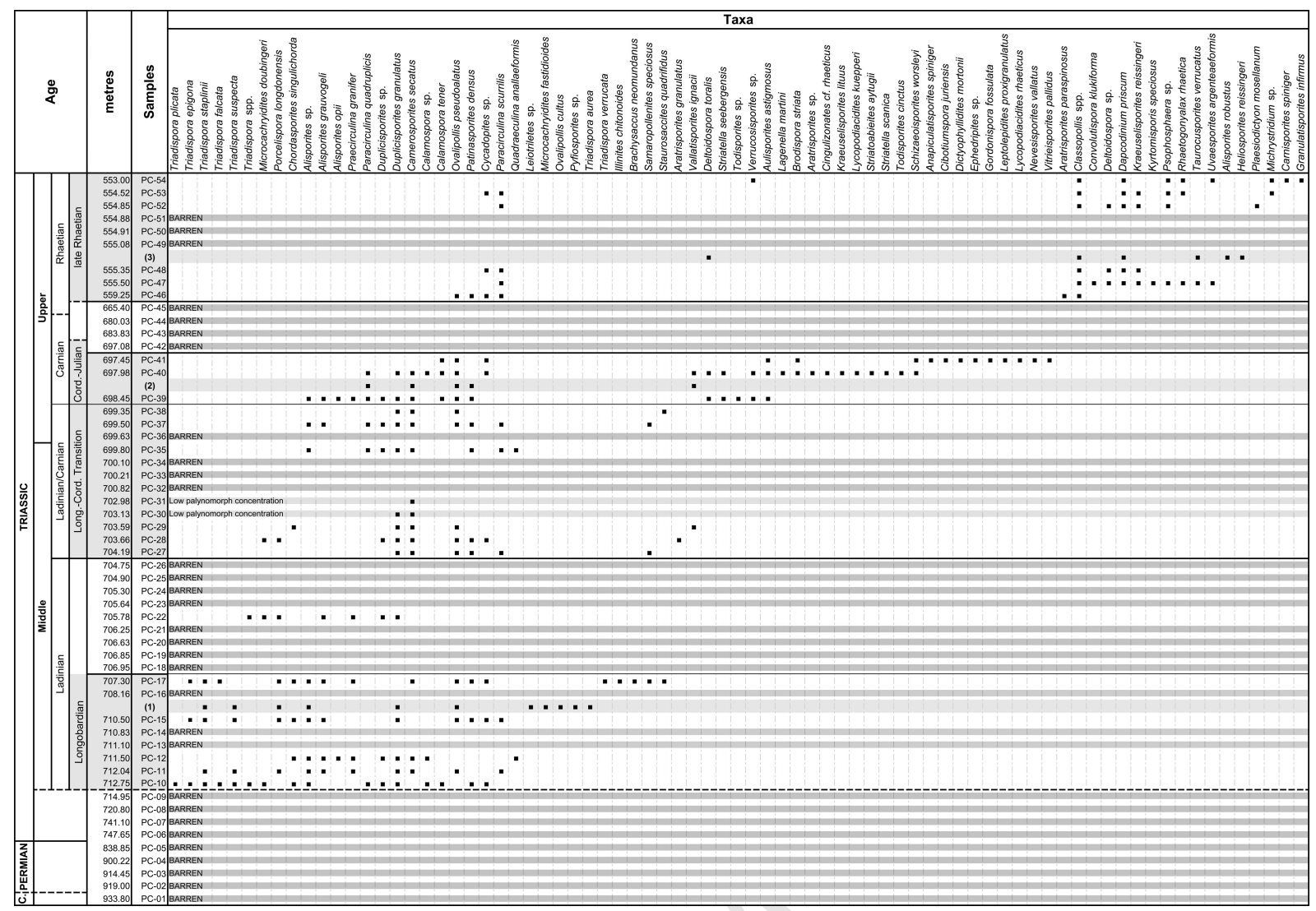

Figure 5 Stratigraphic distribution of the palynological taxa in the study interval. Sample (1):

second assemblage from Adloff et al. (1987) and Courel et al. (1990); sample (2): first assemblage from Adloff et al. (1987); sample (3): assemblage from Lorenz et al. (1987). 

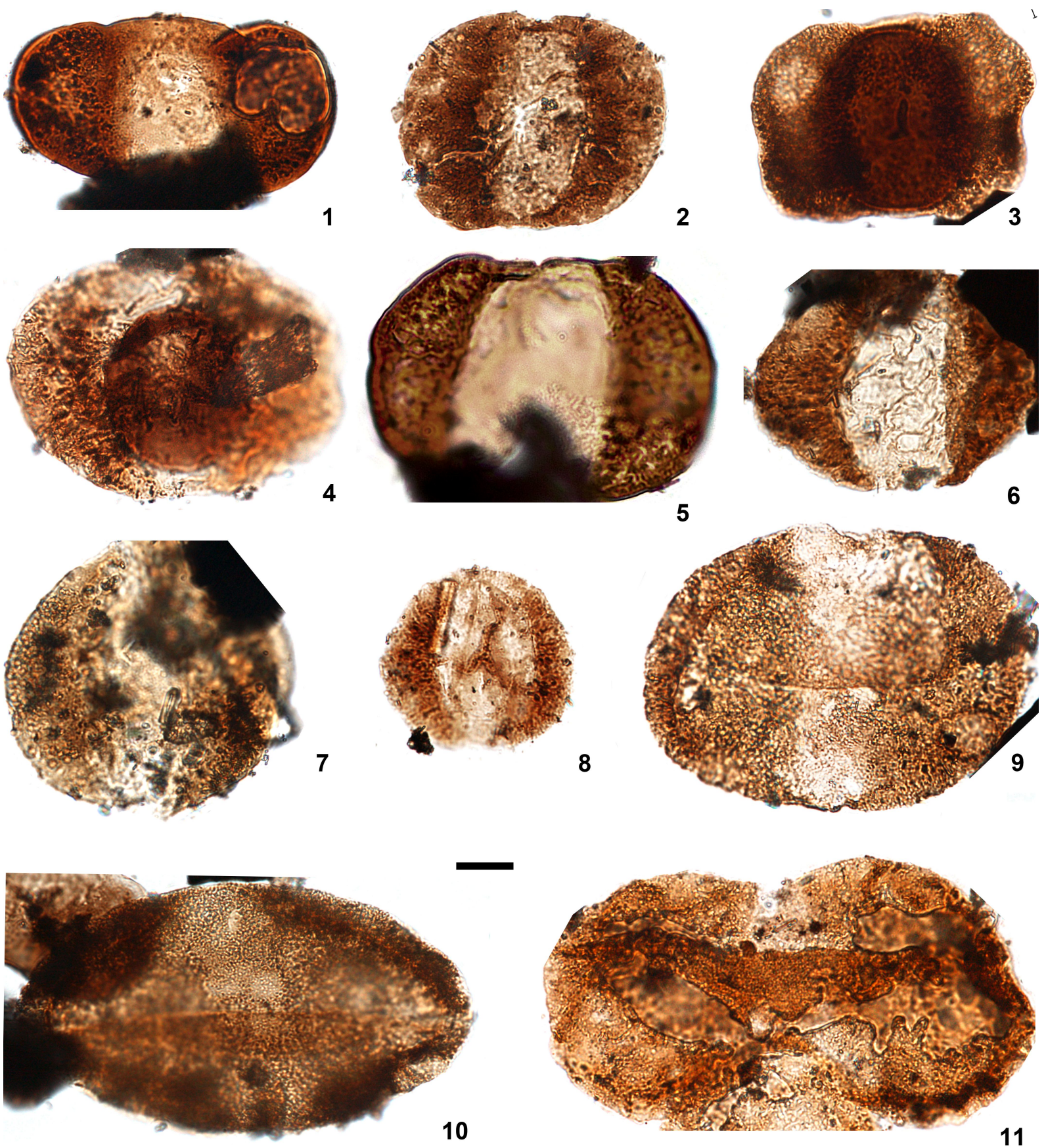

Figure 6 SC-1 palynological assemblage. 1. Triadispora falcata Klaus, 1964. 2. Triadispora staplinii (Jansonius) Klaus, 1964. 3. Triadispora suspecta Scheuring, 1970. 4. Triadispora verrucata (Schulz) Scheuring, 1970. 5. Triadispora plicata Klaus, 1964. 6. Alisporites grauvogeli Klaus, 1964. 7. Alisporites opii Daugherty, 1941. 8. Triadispora epigona Klaus, 1964. 9. Illinites chitonoides Klaus, 1964. 10. Ovalipollis pseudoalatus (Thiergart)

Schuurman, 1976. 11. Staurosaccites quadrifidus Dolby, 1976. Scale bar: $10 \mu \mathrm{m}$. 

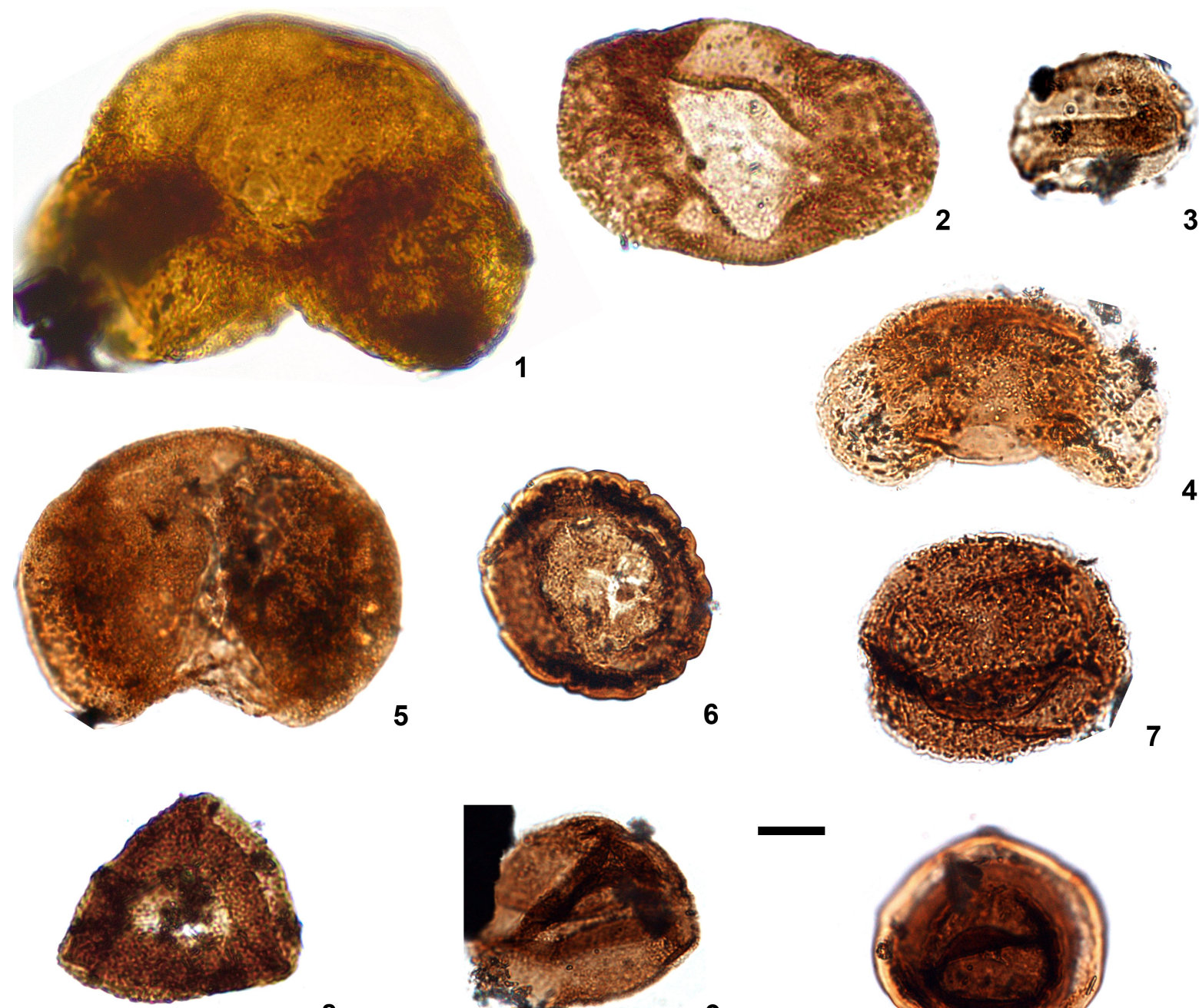

8
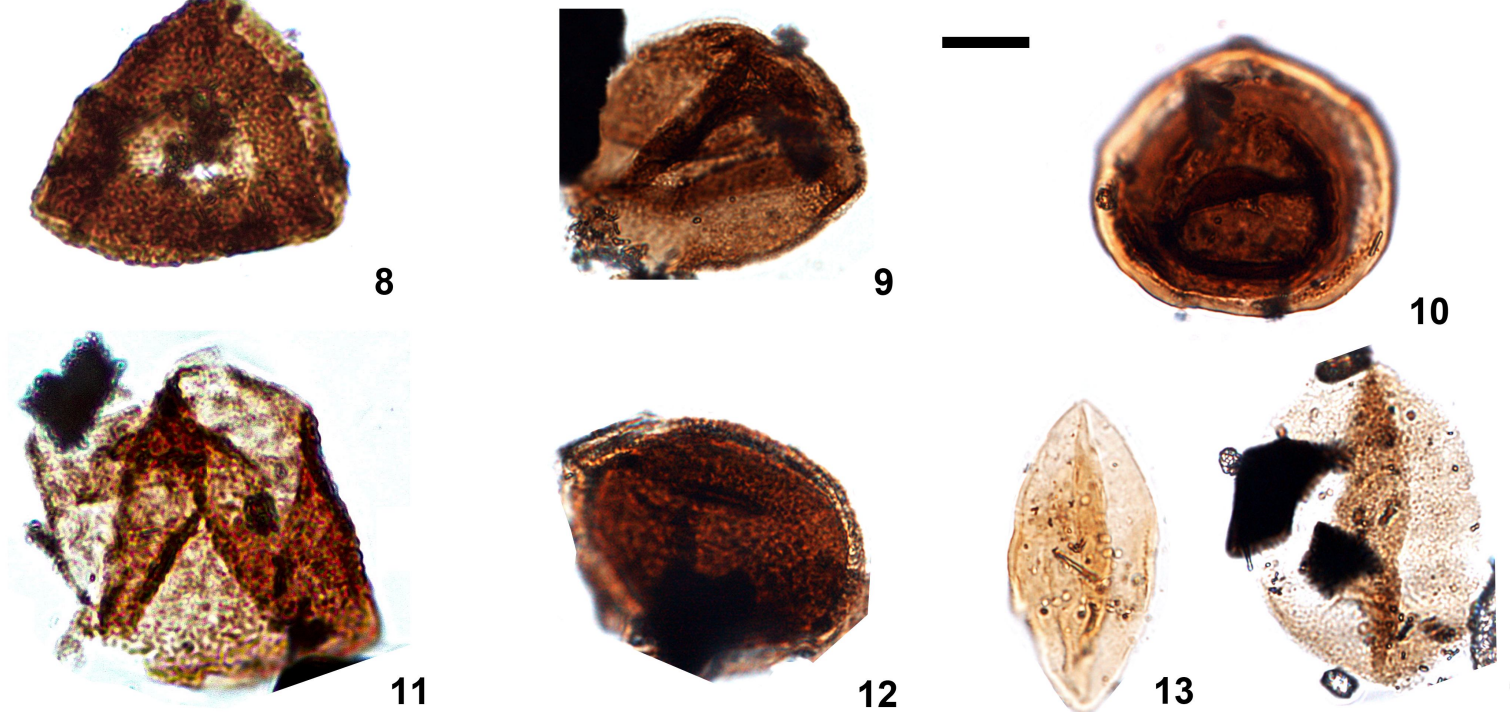

14

Figure 7 SC-1 palynological assemblage. 1. Microcachryidites doubingeri Klaus, 1964. 2.

Chordasporites singulichorda Klaus, 1960. 3. Quadraeculina anellaeformis Maljavkina,

1949. 4. Samaropollenites speciosus Goubin, 1965. 5. Brachysaccus neomundanus (Leschik)

Mädler, 1964. 6. Camerosporites secatus Leschik, 1956. 7. Porcellispora longdonensis

(Clarke) Scheuring, 1970 emend. Morbey, 1975. 8. Duplicisporites granulatus (Leschik)

Scheuring, 1970. 9. Duplicisporites sp. 10. Paracirculina scurrilis Scheuring, 1970. 11. 
Calamospora tener (Leschik) Mädler, 1964. 12. Praecirculina granifer (Leschik) Klaus,

1960. 13, 14. Cycadopites sp. Scale bar: $10 \mu \mathrm{m}$.
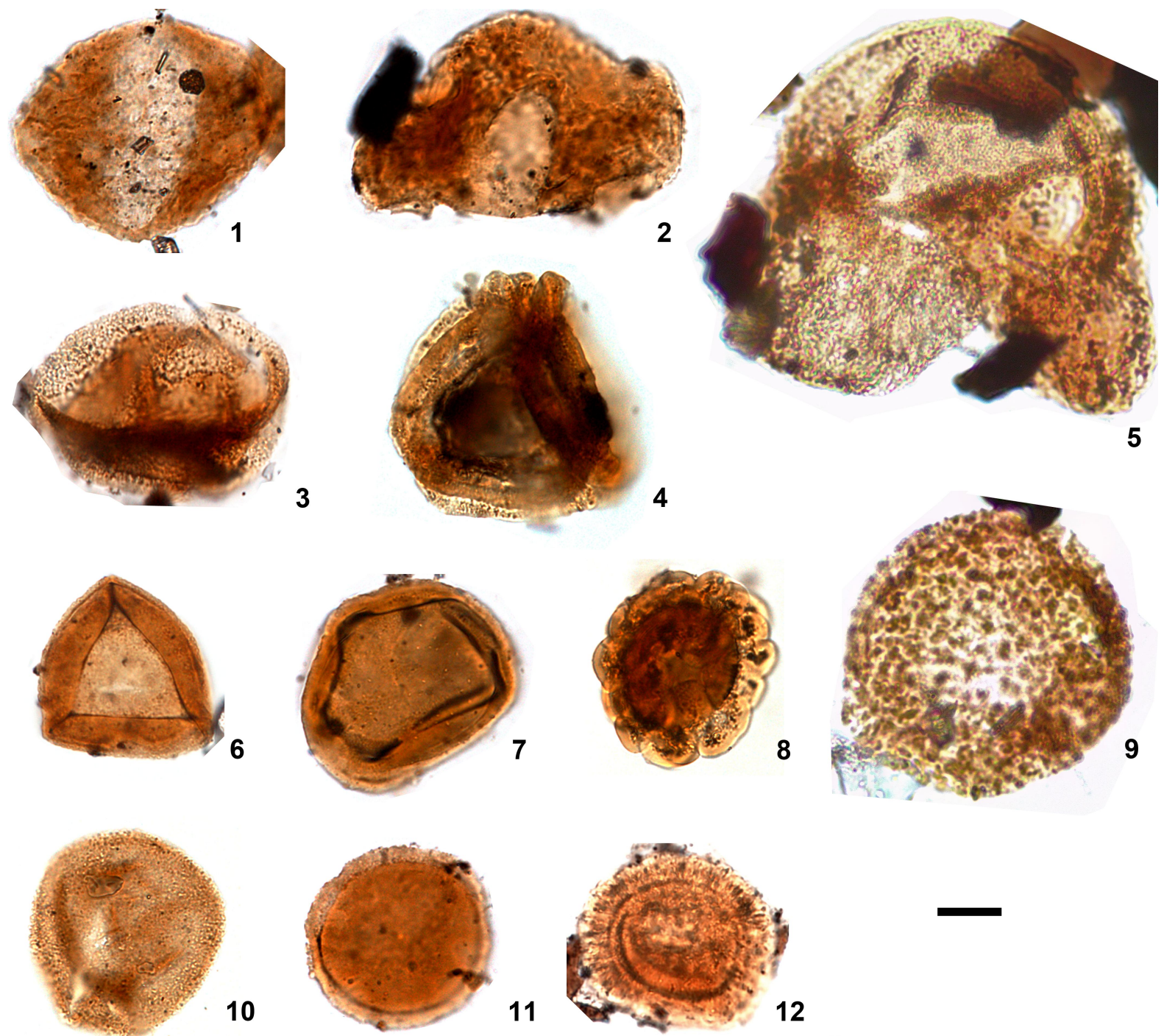

\section{3}

10

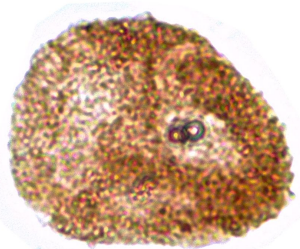

13

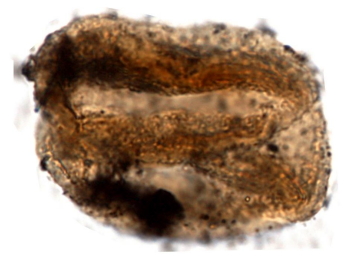

14

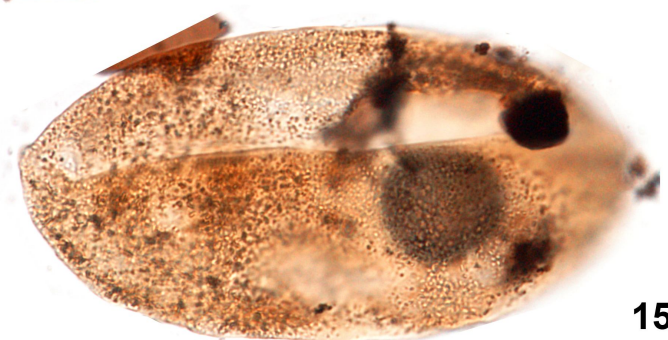

Figure 8 SC-2 palynological assemblage. 1. Alisporites grauvogeli Klaus, 1964. 2.

Samaropollenites speciosus Goubin, 1965. 3. Aratrisporites granulatus Klaus, 1960. 4.

Paracirculina quadruplices Scheuring, 1970. 5. Microcachryidites doubingeri Klaus, 1964. 6.

Duplicisporites granulatus (Leschik) Scheuring, 1970. 7. Duplicisporites sp. 8. 
Camerosporites secatus Leschik, 1956. 9. Porcellispora longdonensis (Clarke) Scheuring,

1970 emend. Morbey, 1975. 10. Praecirculina granifer (Leschik) Klaus, 1960. 11.

Paracirculina scurrilis Scheuring, 1970. 12. Patinasporites densus Leschik, 1955. 13.

Vallasporites ignacii Leschik, 1956. 14. Quadraeculina anellaeformis Maljavkina, 1949. 15.

Ovalipollis pseudoalatus (Thiergart) Schuurman, 1976. Scale bar: $10 \mu \mathrm{m}$.
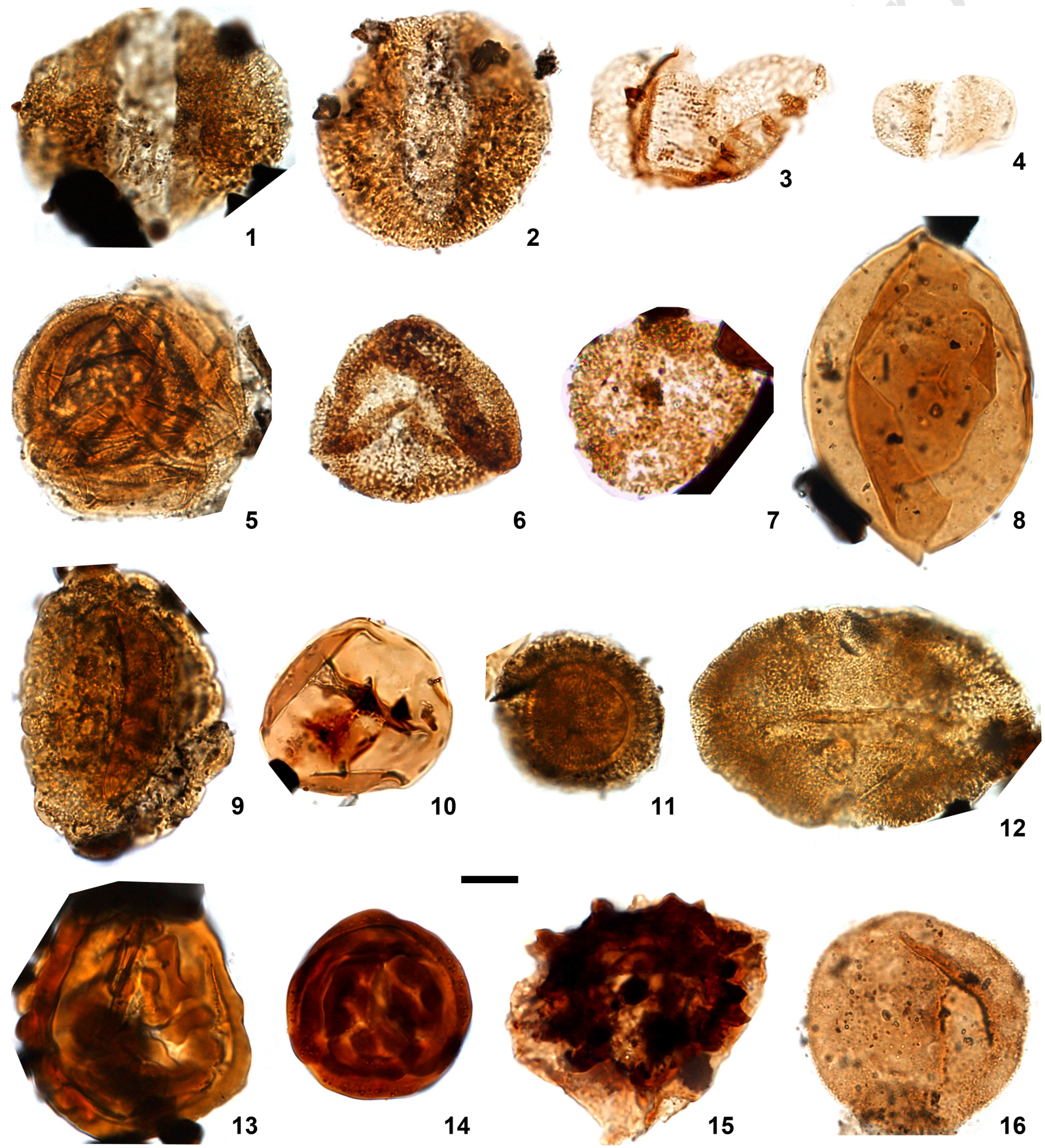

Figure 9 SC-3 palynological assemblage. 1. Alisporites grauvogeli Klaus, 1964. 2. Alisporites 
opii Daugherty, 1941. 3. Striatoabieites aytugii (Visscher) Scheuring, 1970. 4. Vitreisporites pallidus (Reissinger) Nilsson, 1958. 5. Paracirculina quadruplices Scheuring, 1970. 6. Duplicisporites granulatus (Leschik) Scheuring, 1970. 7. Vallasporites ignacii Leschik, 1956. 8. Aulisporites astigmosus (Leschik) Klaus, 1960. 9. Camerosporites secatus Leschik, 1956. 10. Calamospora tener (Leschik) Mädler, 1964. 11. Patinasporites densus Leschik, 1955. 12. Ovalipollis pseudoalatus (Thiergart) Schuurman, 1976. 13. Striatella seebergensis Mädler, 1964. 14. Striatella scanica (Nilsson) Filatoff et Price, 1988. 15. Kraeuselisporites lituus (Leschik) Scheuring, 1974. 16. Praecirculina granifer (Leschik) Klaus, 1960. Scale bar: 10 $\mu \mathrm{m}$. 

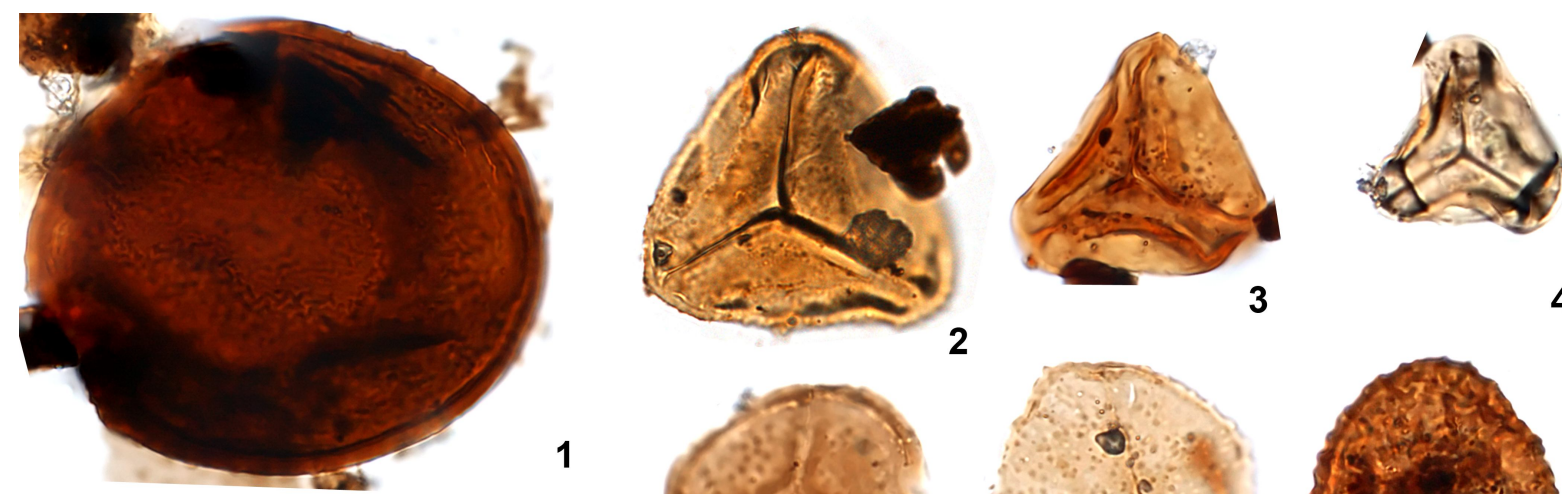

3

4
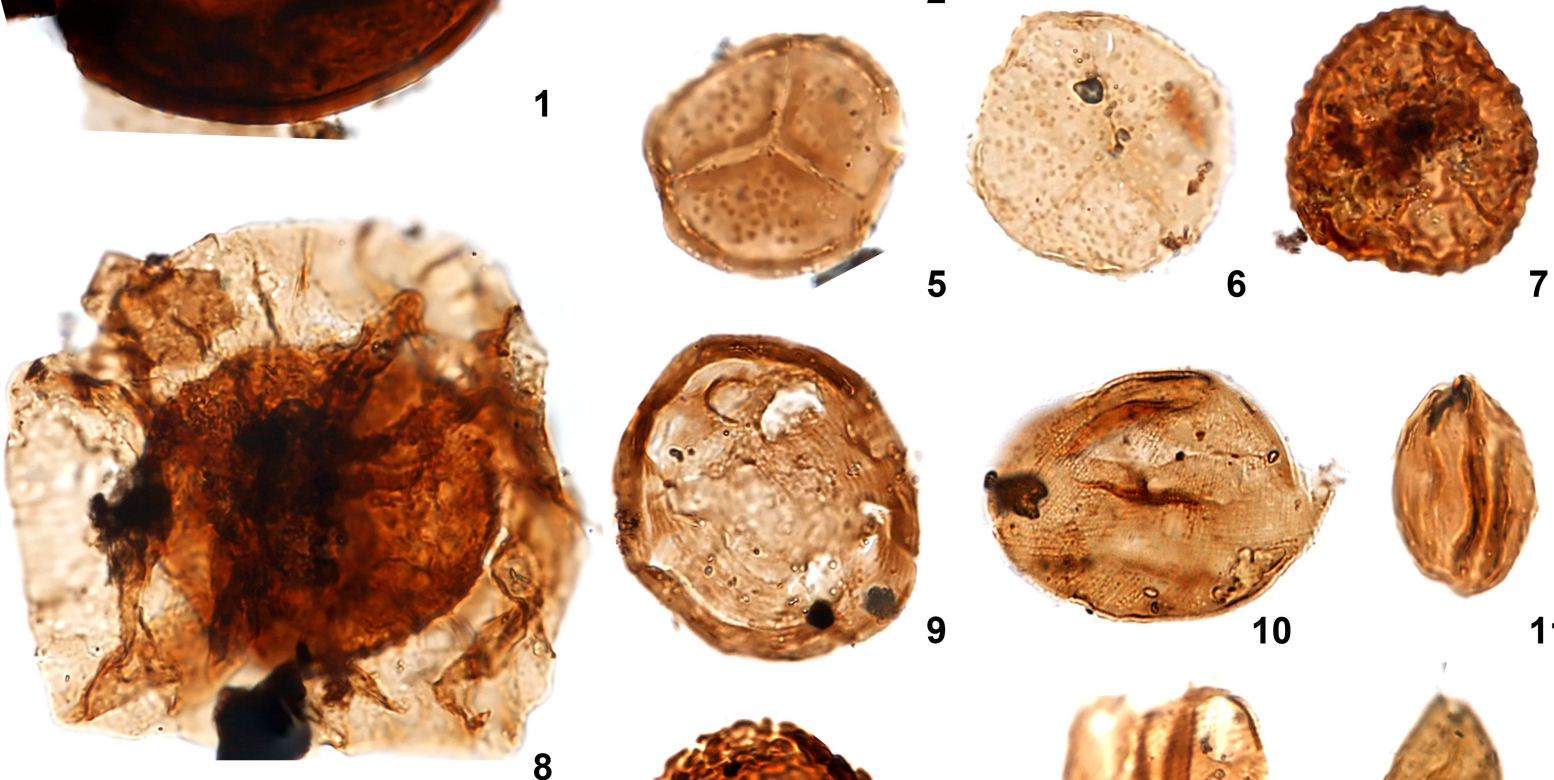

8

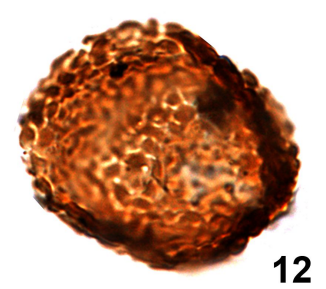

12
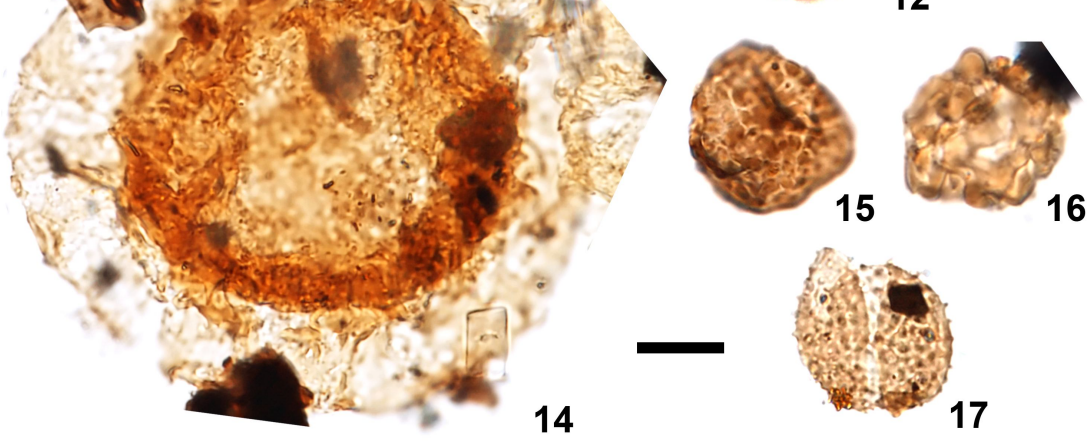

17

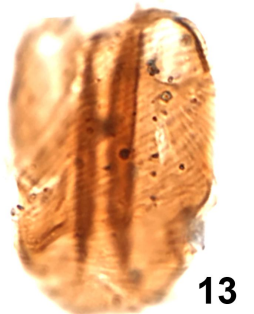

13

16
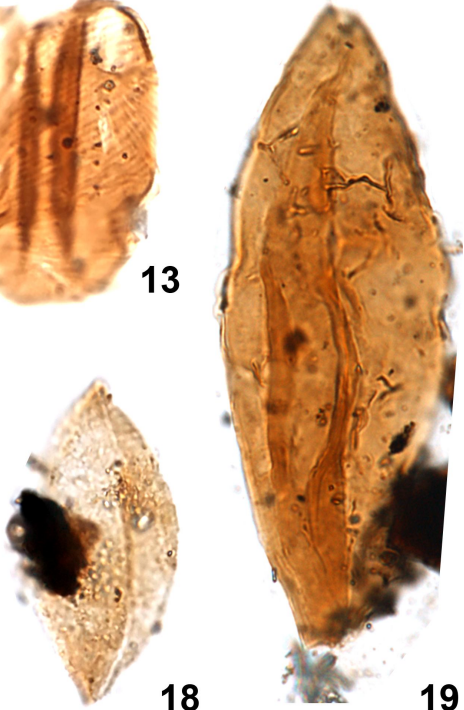

Figure 10 SC-3 palynological assemblage. 1. Todisporites cinctus (Maljavkina) Orlowska-

Zwolinska, 1971. 2. Deltoidospora toralis (Leschik) Lund, 1977. 3. Dictyophyllidites

mortonii (de Jersey) Playford et Dettmann, 1965. 4. Cibotiumspora juriensis (Balme) Filatoff, 1975. 5. Gordonispora fossulata (Balme 1970) Van Der Eem, 1983. 6. Nevesisporites vallatus de Jersey et Paten, 1964. 7. Lycopodiacidites kuepperi Klaus, 1960. 8, 9. Brodispora striata Clarke, 1965. 10. Lagenella martini (Leschik) Klaus, 1960. 11. Ephedripites sp. 12. 
Verrucosisporites sp. 13. Schizaeoisporites worsleyi Bjærke et Manum, 1977. 14.

Cingulizonates sp. cf. Cingulizonates rhaeticus (Rheinhardt) Schulz, 1967. 15.

Lycopodiacidites rhaeticus Schulz, 1967. 16. Leptolepidites proxigranulatus (Brenner)

Dörhöfer, 1979. 17. Anapiculalisporites spiniger (Leschik) Reinhardt, 1962. 18, 19.

Cycadopites sp. Scale bar: $10 \mu \mathrm{m}$. 

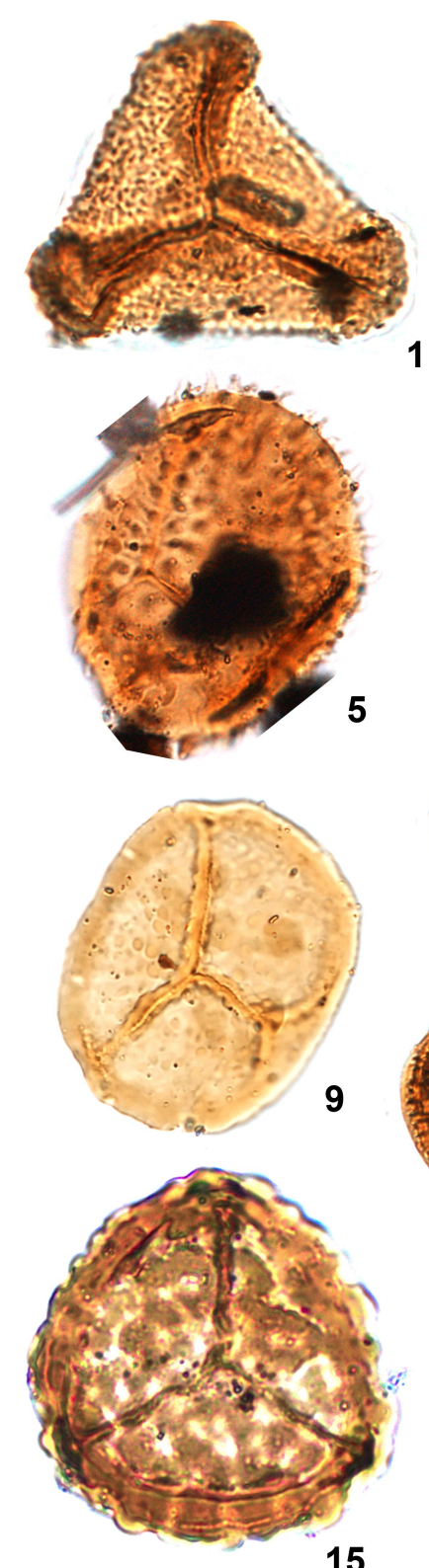

15

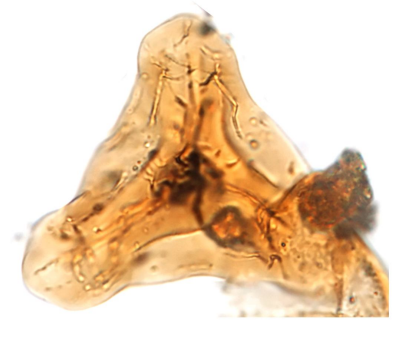

2

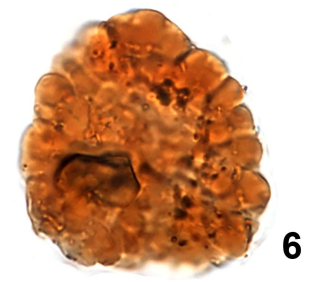

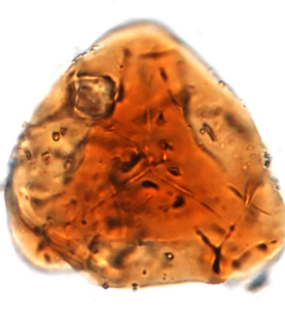

3
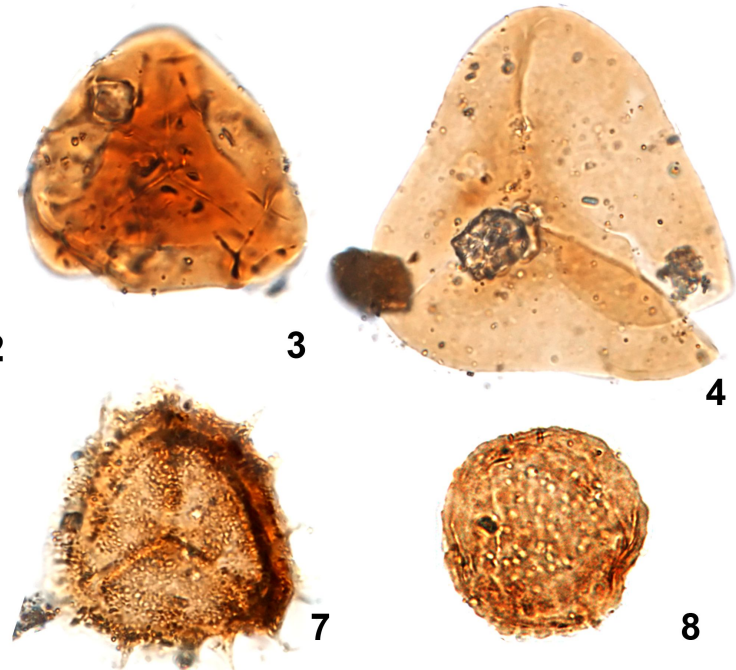
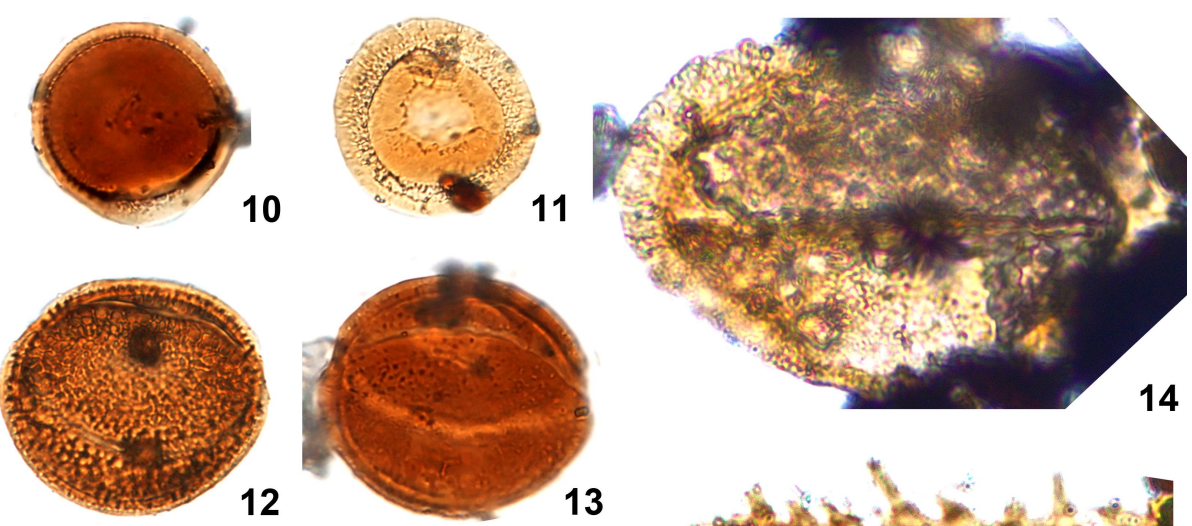

13
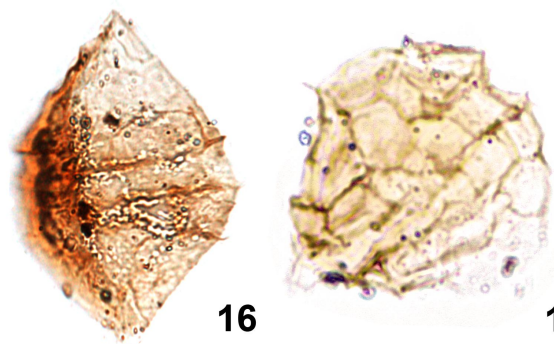

17
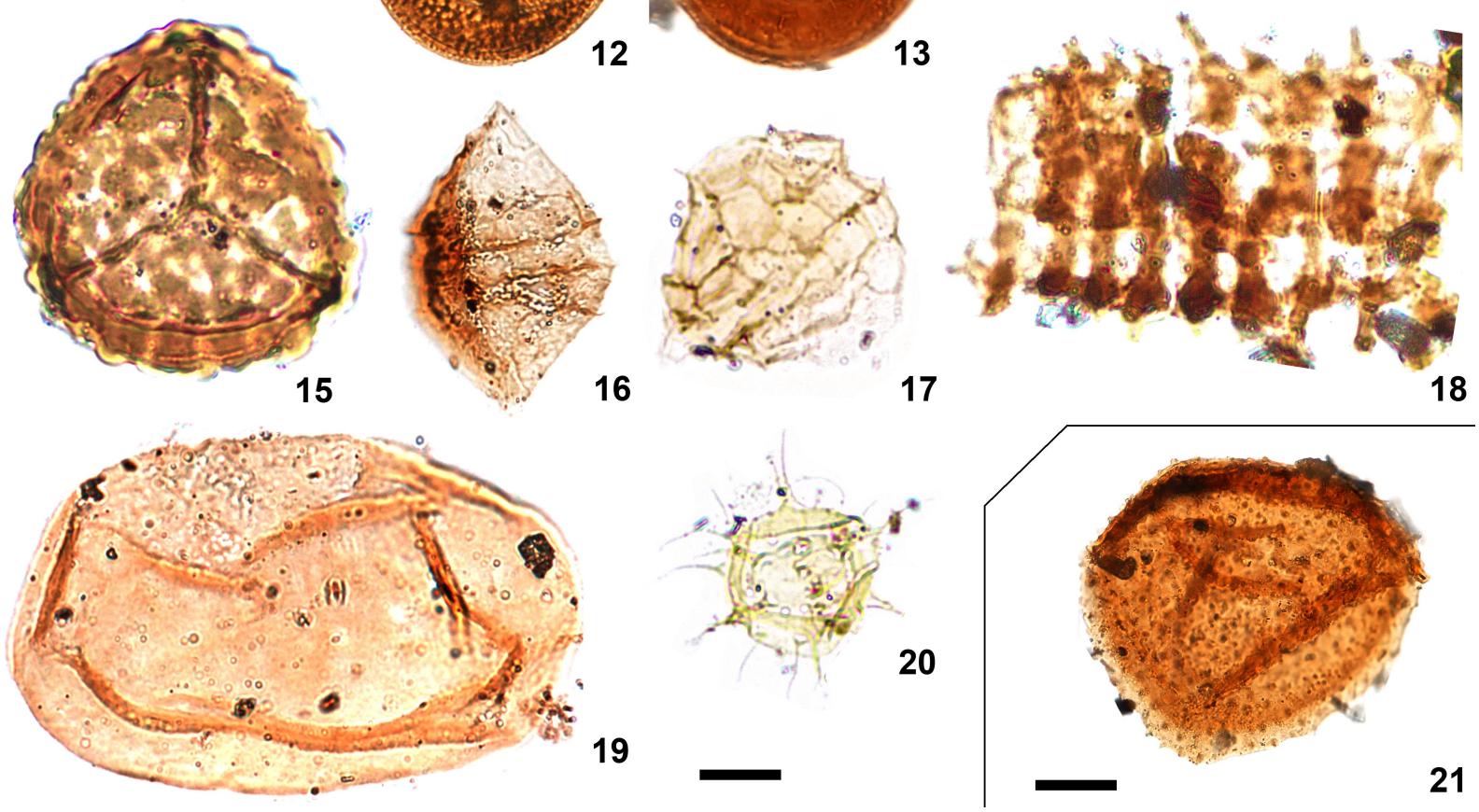

Figure 11 SC-4 palynological assemblage. 1. Granulatisporites infirmus (Balme) Cornet et

Traverse, 1975. 2. Kyrtomisporis speciosus Mädler, 1964. 3. Cibotiumspora sp. 4.

Deltoidospora sp. 5. Carnisporites spiniger (Leschik) Morbey, 1975. 6. Uvaesporites

argenteaeformis (Bolkhovitina) Schulz, 1967. 7. Kraeuselisporites reissingeri (Harris) 
Morbey, 1975. 8. Verrucosisporites sp. 9. Taurocusporites verrucatus Schulz, 1967. 10.

Paracirculina scurrilis Scheuring, 1970. 11. Patinasporites densus Leschik, 1955. 12.

Classopollis torosus (Reissinger) Balme, 1957. 13. Classopollis meyeriana (Klaus) de Jersey, 1973. 14. Ovalipollis pseudoalatus (Thiergart) Schuurman, 1976. 15. Convolutispora klukiforma (Nilsson) Schulz, 1967. 16. Rhaetogonyaulax rhaetica (Sarjeant) Loeblich et Loeblich, 1968. 17. Dapcodinium priscum Evitt, 1961. 18. Plaesiodictyon mosellanum Wille, 1970. 19. Psophosphaera sp. 20. Michrystridium sp. 21. Aratrisporites paraspinosus Klaus, 1960. Scale bars: $10 \mu \mathrm{m}$ 1-20), $20 \mu \mathrm{m}(21)$. 


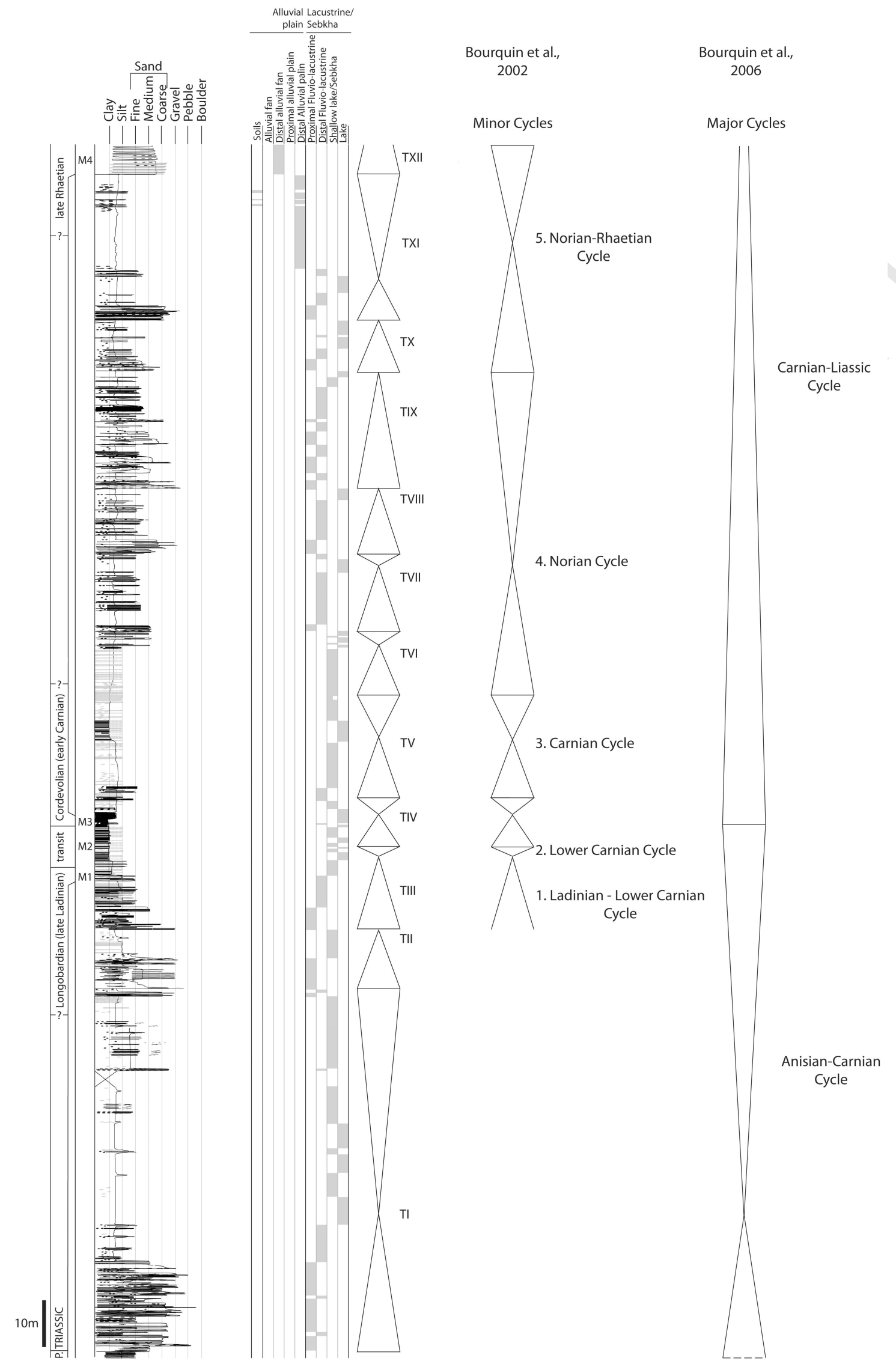

Figure 12 Comparison of the stratigraphic cycles between results of the present study and 
previous studies based on well-log data.

Table 1 Facies description and interpretation of the Permian and Triassic series in the Sancere-Couy core.

\begin{tabular}{lll}
\hline Facies Lithology & Sedimentary structure & Depositional process \\
Code & &
\end{tabular}

Fine facies

F $\quad$ Silt or silty clay, red to

Massive or laminated

Deposition from

black

suspension

$\mathrm{Fb} \quad$ Silt or silty clay, red to

Massive or laminated

Deposition from

black

bioturbated,

suspension within a

permanent water body

allowing reworking by

biological activity

Fl

Heterolithic facies

composed of silt or silty

clay interbedded with $\mathrm{cm}$

to dm-thick beds of sand

cross-laminated,

horizontally laminated

or massive sand

Flb Heterolithic facies

comnoced of cilt or cilty
Massive or laminated,

Deposition from

interhedded with rinnle cucnancion altarnatina 


$\begin{array}{lll}\text { composed of silt or silty } & \text { interbedded with ripple } & \text { suspension alternating } \\ \text { clay interbedded with } \mathrm{cm} & \text { cross-laminated, } & \text { with overbanks, waning } \\ \text { to dm-thick beds of sand } & \text { horizontally laminated } & \text { floods or turbidity } \\ & \text { or massive sand, } & \text { currents within a } \\ & \text { bioturbated, sometimes } & \text { permanent water body } \\ & \text { with oscillatory ripples } & \text { allowing reworking by } \\ & & \text { biological activity } \\ \text { Silt or silty clay, with } & \text { Massive } & \text { High energy, margin lake } \\ \text { oolithe } & & \end{array}$

Fo Silt or silty clay, with Massive High energy, margin lake

Sandstone facies

$\mathrm{Sr}$

Fine to medium sand Ripple cross-

Current ripples, lower

laminations

part of the lower flow

regime (Miall, 1978)

Srb

Fine to medium sand

Ripple cross-

Tractive current

laminations, bioturbated reworking by biological

activity

$\mathrm{Sw}$

Fine to medium sand Oscillatory ripples

Deposition or reworking

by waves

$\mathrm{Sm}$
Fine to coarse sand
with sometimes
scattered gravels

Massive, sharp basal

Subaerial

and top boundaries,

hyperconcentrated

sometimes Normally-

density flow or

graded

subaqueous high-density

turbidity current (Lowe, 
1982; Mulder \&

Alexander, 2001); rapid

suspension fallout

(Postma, 1990)

$\mathrm{Smb}$

Fine to coarse sand

Massive, progressive or

Subaqueous high-density

sharp basal and top

turbidity current (Lowe,

boundaries

1982; Mulder \&

Alexander, 2001); rapid

suspension fallout

(Postma, 1990),

reworking by biological

activity

Sh

Fine to coarse sand, Planar or sub-planar

Tractive current, upper

well to poorly sorted,

laminations, current

flow regime (Miall,

sometimes with mud

lineations, sharp basal

1978)

clasts or chips

and top boundaries

underlining the

stratification or

scattered gravels

Medium to coarse sand Through cross-

Tractive current, upper

stratifications, sharp or

part of the lower flow

erosive basal boundary

regime, 3D megaripple

migration (Miall, 1978) 


\begin{tabular}{|c|c|c|c|}
\hline \multirow[t]{4}{*}{$\mathrm{Gmm}$} & Angular to sub- & Massive, ungraded or & Debris flow (Postma \\
\hline & rounded gravels to & with a normal grading to & 1990; Miall, 1996) \\
\hline & pebbles (up to $3 \mathrm{~cm}$ ), & the top, erosive basal & \\
\hline & very poorly sorted, & boundary & \\
\hline
\end{tabular}

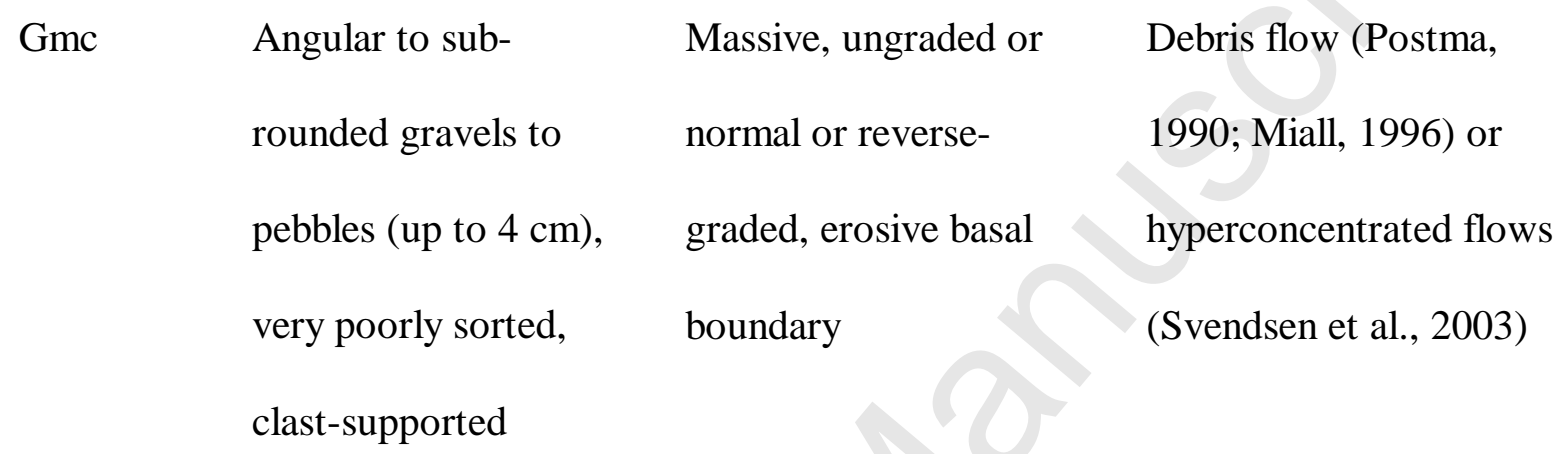

Gh Angular to sub-

Horizontal to sub-

Traction carpets driven rounded gravels to horizontal stratifications by streamflow (Postma, pebbles, very poorly erosive or sharp basal 1990), upper flow sorted boundary, sharp top regime (Miall, 1978) boundary

$\mathrm{Gp}$ Angular to sub-

Planar cross Traction carpets driven rounded gravels to stratifications, erosive by streamflow (Postma, pebbles, very poorly basal boundary, sharp 1990), upper flow sorted top boundary regime (Miall, 1978) 
Dolomitic and anhydrite facies

A

$\mathrm{Fa}$

Fn

Dn

Dm

Ds
Sebkha

Sebkha

Dolocrete

Dolocrete

Shallow lake lake

Stromatolitic bed,

marginal-shallow lake 